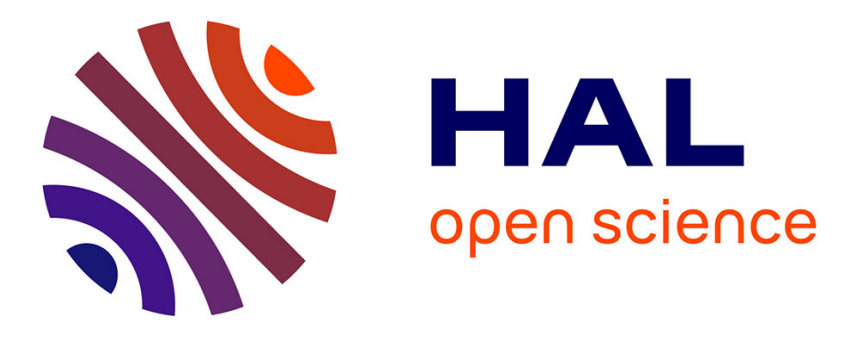

\title{
Dolphins in a Scaled-Down Mediterranean
}

\author{
G. Bearzi, S. Bonizzoni, N.L. L Santostasi, N.B. B Furey, L. Eddy, V.D. D \\ Valavanis, O. Gimenez
}

\section{To cite this version:}

G. Bearzi, S. Bonizzoni, N.L. L Santostasi, N.B. B Furey, L. Eddy, et al.. Dolphins in a Scaled-Down Mediterranean. Mediterranean Marine Mammal Ecology and Conservation, 75, Elsevier, pp.297-331, 2016, Advances in Marine Biology, 10.1016/bs.amb.2016.07.003 . hal-03515145

\section{HAL Id: hal-03515145 \\ https://hal.science/hal-03515145}

Submitted on 19 Jan 2022

HAL is a multi-disciplinary open access archive for the deposit and dissemination of scientific research documents, whether they are published or not. The documents may come from teaching and research institutions in France or abroad, or from public or private research centers.
L'archive ouverte pluridisciplinaire HAL, est destinée au dépôt et à la diffusion de documents scientifiques de niveau recherche, publiés ou non, émanant des établissements d'enseignement et de recherche français ou étrangers, des laboratoires publics ou privés. 


\title{
Dolphins in a Scaled-Down Mediterranean: The Gulf of Corinth's Odontocetes
}

\author{
G. Bearzi ${ }^{*, t,+, 1}$, S. Bonizzoni ${ }^{*,+,}$, N.L. Santostasi ${ }^{*, \S}$, N.B. Furey ${ }^{*}$, II \\ L. Eddy ${ }^{*},{ }^{\dagger}$, V.D. Valavanis ${ }^{\|}$, O. Gimenez ${ }^{\S}$ \\ *Dolphin Biology and Conservation, Oria, Italy \\ †OceanCare, Wädenswil, Switzerland \\ "Texas A\&M University at Galveston, Galveston, TX, United States \\ ${ }^{\S}$ Centre d'Ecologie Fonctionnelle et Evolutive, Montpellier, France \\ "University of British Columbia, Vancouver, BC, Canada \\ ${ }$ Marine Geographic Information Systems Lab, Hellenic Centre for Marine Research, Heraklion, Greece \\ ${ }^{1}$ Corresponding author: e-mail address: giovanni.bearzi@gmail.com
}

\section{Contents}

1. Introduction 2

2. Methods 4

2.1 Study Area 4

2.2 Survey and Photo-Identification Effort 6

$\begin{array}{ll}2.3 \text { Mixed Groups } & 10\end{array}$

2.4 Capture-Recapture Analyses 12

$\begin{array}{lll}2.5 & \text { Distribution Modelling } & 12\end{array}$

$\begin{array}{ll}2.6 \text { Assessment of Fishing Fleets } & 14\end{array}$

3. Results 15

3.1 Striped and Short-Beaked Common Dolphins 15

$\begin{array}{ll}3.2 \text { Risso's Dolphin } & 17\end{array}$

3.3 Common Bottlenose Dolphins $\quad 17$

3.4 Other Marine Fauna 18

$\begin{array}{ll}3.5 \text { Fishing Fleet } & 20\end{array}$

4. Discussion 20

4.1 Geographic Isolation and Genetic Differentiation 20

$\begin{array}{ll}4.2 \text { Striped Dolphins } & 21\end{array}$

4.3 Short-Beaked Common Dolphins and Mixed-Species Groups
with Striped Dolphins

4.4 Common Bottlenose Dolphins 23

4.5 Other Species 24

4.6 Anthropogenic Impacts $\quad 25$

$\begin{array}{ll}4.7 \text { Conclusions } & 27\end{array}$

$\begin{array}{ll}\text { Acknowledgements } & 27\end{array}$

$\begin{array}{ll}\text { References } & 27\end{array}$ 


\section{Abstract}

The Gulf of Corinth is a 2400- $\mathrm{km}^{2}$ semi-enclosed inland system (a mediterraneus) in central Greece. Its continental shelf areas, steep bottom relief, and waters up to 500-900 m deep offer suitable habitat to neritic and pelagic species. We used photographic capture-recapture, distribution modelling, and direct observations to investigate the abundance, status, habitat preferences, movements, and group size of four odontocete species regularly observed in the Gulf, based on five years (2011-2015) of survey effort from small boats. Striped dolphins (Stenella coeruleoalba) are more abundant (1324 individuals, 95\%Cl 1158-1515) than was determined from previous estimates. Striped dolphins appear to be confined to the Gulf, where they favour deep and oligotrophic waters, and were encountered in single-species and mixed-species groups. Shortbeaked common dolphins (Delphinus delphis) (22 individuals, $95 \% \mathrm{Cl} 16-31$ ), individuals with intermediate pigmentation (possibly striped/common dolphin hybrids) $(55,95 \% \mathrm{Cl}$ 36-83), and a single Risso's dolphin (Grampus griseus) were only encountered in mixedspecies groups with striped dolphins. Short-beaked common dolphins constitute a discrete conservation unit (subpopulation), and based on the current estimate, would qualify as Critically Endangered according to International Union for the Conservation of Nature (IUCN) Red List criteria. Common bottlenose dolphins (Tursiops truncatus) (39 animals, 95\% Cl 33-47) occur in single-species groups; they prefer continental shelf waters and areas near fish farms in the northern sector, and several animals appear to move into and out of the Gulf. Additionally, we contribute records of marine fauna and an assessment of the fishing fleet operating in the Gulf. Our study shows that the importance of this vulnerable marine environment has been underestimated, and management action must be taken to mitigate human impact and ensure long-term protection.

\section{INTRODUCTION}

In the Mediterranean Sea, formal commitments to protect cetaceans clash with geopolitical complexity, socio-economic or naval interests, and a generally poor political resolve, resulting in inaction. Beyond the political arena, a poor understanding of ecological components in the region leads to yet another reason for inertia (Portman et al., 2013). Though action may not be taken even when extensive information does become available (Bearzi, 2007), lack of information will invariably undermine marine conservation efforts. Therefore, contributing rigorous data on cetacean population abundance, status, distribution, and movements is a fundamental first step.

The Gulf of Corinth (GOC) is a semi-enclosed embayment in central Greece. Its intracontinental rift-one of Earth's most active and fastest spreading (Beckers et al., 2015; Taylor et al., 2011)_-generated a fault along 
the Gulf's southern margin, where waters 500-900 m deep are found close to the coast. The occurrence of continental shelf areas, steep bottom relief, and deep waters within a $2400-\mathrm{km}^{2}$ inland basin gave rise to a scaled-down Mediterranean (literally meaning 'in the middle of the land') that offers suitable habitat to a variety of neritic and pelagic species. Striped dolphins (Stenella coeruleoalba) — a typically pelagic odontocete (Aguilar and Gaspari, 2012; Archer, 2009)_occur near the coast and are abundant (Frantzis and Herzing, 2002). Research conducted since the mid-1990s has documented mixed-species groups including striped and short-beaked common dolphins (Delphinus delphis) (Azzolin et al., 2010; Bearzi et al., 2011a; Frantzis and Herzing, 2002; Frantzis et al., 2003; Gkafas et al., 2007; Mardikis et al., 1999; Podiadis et al., 2003; Zafiropoulos et al., 1999). Animals with intermediate striped-common dolphin pigmentation were also observed and are suspected to be hybrids (Bearzi et al., 2011a; Frantzis and Herzing, 2002). Additionally, between 1997 and 2001 two Risso's dolphins (Grampus griseus) were found within groups of striped and common dolphins (Frantzis and Herzing, 2002). A fourth odontocete encountered in the GOC is the common bottlenose dolphin (Tursiops truncatus). Bottlenose dolphins were never observed in mixed-species groups and some individuals were documented to range as far as $265 \mathrm{~km}$, moving into and out of the GOC (Bearzi et al., 2011b).

Ensuring conservation of odontocetes occurring in the GOC is crucial, particularly when one considers the status of these species in the broader Mediterranean region (Notarbartolo di Sciara and Birkun, 2010). Striped dolphins are the most abundant cetaceans in the Mediterranean Sea (Aguilar, 2000), including in the waters of Greece (Frantzis et al., 2003). However, they have been classified as Vulnerable on the IUCN Red List of Threatened Species, primarily because of past mortality events caused by viral infections (related to contamination by xenobiotics), incidental capture in pelagic driftnets, and decreased food availability caused by overfishing (Aguilar and Gaspari, 2012). Common dolphins were once abundant, but since the 1960s they have been declining dramatically throughout the Mediterranean and are currently classified as Endangered (Bearzi, 2003). The causes of their decline include historical culling and, more recently, prey depletion by overfishing, incidental mortality in fishing gear, and sea temperature shifts related to climate change (Bearzi et al., 2003, 2008a; Cañadas and Vázquez, in press). The status of Risso's dolphins is poorly known and their Mediterranean subpopulation is classified as Data Deficient (Bearzi et al., 2011c; Gaspari and Natoli, 2012). Finally, bottlenose dolphins in 
the Mediterranean are classified as Vulnerable due to declines as a result of culling, overfishing of their prey, mortality in fishing gear, and health effects caused by pollution (Bearzi et al., 2008b, 2012).

Several management measures to protect cetaceans in the GOC have been proposed, but no action has been taken to date. In 2007, the Agreement on the Conservation of Cetaceans of the Black Sea, Mediterranean Sea, and Contiguous Atlantic Area (ACCOBAMS) (also ratified by Greece) listed the GOC as an area of special importance for common dolphins and other cetaceans, and called for the creation of a Marine Protected Area (MPA) (resolution 3.22; ACCOBAMS, 2007). In the same year, Greenpeace proposed the creation of a marine reserve (Greenpeace, 2007). A National Strategy and Action Plan for the Conservation of Cetaceans in Greece, 2010-2015, granted high conservation priority to the GOC (Notarbartolo di Sciara and Bearzi, 2010). More recently, the European Union (EU) funded project, Monitoring and Evaluation of Spatially Managed Areas (MESMA) proposed a network of MPAs including parts of the GOC (Giakoumi et al., 2012; Issaris et al., 2012; Stelzenmüller et al., 2013; Vassilopoulou et al., 2012). Though praiseworthy, these efforts were based on limited and preliminary information (e.g. regarding population sizes of individual species, habitat preferences, movement patterns, and current anthropogenic stressors).

Here, we present methodology and results from five years (2011-2015) of field research in the GOC, to provide insight on the biology and ecology of these four odontocete species. Data from boat surveys that encompassed the entire Gulf are combined with oceanographic datasets and measures of human impact to describe cetacean distribution and habitat preferences. Photographic sampling and individual photo-identification are used to obtain abundance estimates for each species, and for animals of intermediate pigmentation (thought to be hybrids). In addition, we provide ancillary information on dolphin group size and behaviour, records of marine fauna, and an assessment of the active fishing fleet.

\section{METHODS}

\subsection{Study Area}

The GOC, between the Peloponnese and mainland Greece, is a semienclosed basin of $2400 \mathrm{~km}^{2}$ marked by broad bays (Fig. 1). The 1.9km-wide Strait of Rion separates the GOC from the outer Gulf of Patras. The 6.4-km long Corinth Canal, cutting through the narrow Isthmus of Corinth, connects the GOC to the Saronic Gulf and the Aegean Sea; it is 


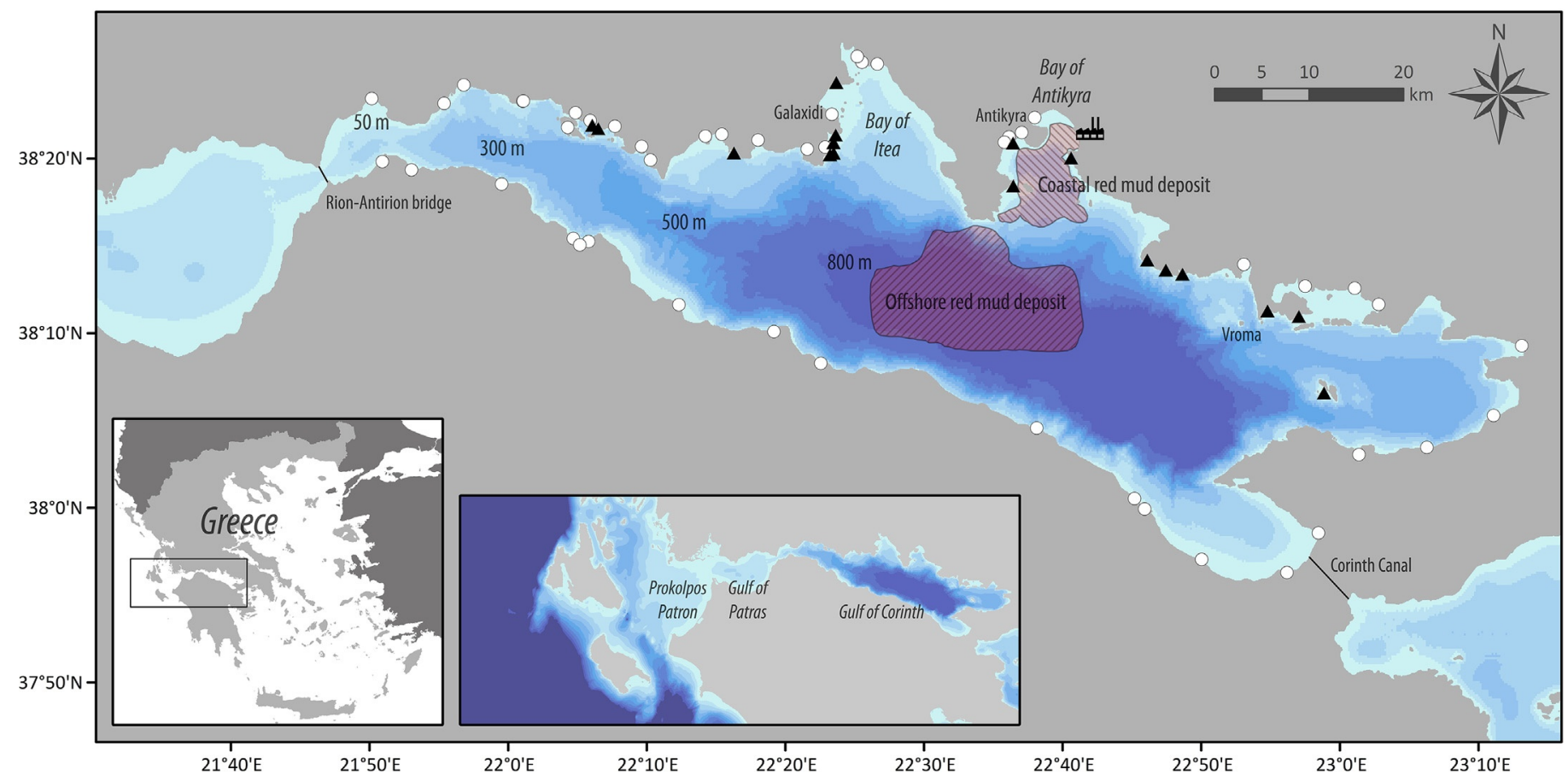

Fig. 1 The Gulf of Corinth. Important locations for the current study, 50-800 m isobaths, perimeter of coastal and offshore red mud deposits, positions of 17 active fish farms (black triangles), and 47 ports, as well as other shelters where fishing boats were recorded (white dots), are shown. Insets show the position of the Gulf in Greece and its inland deep-water basin separated from open lonian Sea waters by the shallow Gulf of Patras and Prokolpos Patron. 
only $21.4 \mathrm{~m}$ wide and $8 \mathrm{~m}$ deep, making it impassable for most modern large ships. The canal is also largely inaccessible to cetaceans (Frantzis and Herzing, 2002). The central portion of the GOC includes a vast extension of waters $500-900 \mathrm{~m}$ deep, encompassing $900 \mathrm{~km}^{2}$. The Gulfs western quarter is shallower $(200-400 \mathrm{~m})$, with a constriction less than $2 \mathrm{~km}$ wide and a maximum depth of $65 \mathrm{~m}$ at the Rion-Antirion Bridge (Fig. 1).

The Gulf waters are generally oligotrophic, with rivers that are mostly seasonal/temporal and limited water intake from small streams. Input of pollutants comes primarily from industrial discards, city sewage, and agriculture runoff (Botsou and Hatzianestis, 2012). A large factory processing bauxite for aluminium production has been operating since 1966, near the city of Antikyra (Fig. 1). The industrial residual after extraction of aluminium (the Bayer process used for refining bauxite results in a by-product called 'red mud') has been dumped into the GOC for decades. Red mud, primarily composed of iron oxides, aluminium, and titanium, has a fine granulometry leading to great dispersion in water (Tsakiridis et al., 2004). Until 1969, red mud was discarded by barges in waters less than $50 \mathrm{~m}$ deep. Increased industrial production led to the construction of a series of underwater pipes, discarding red mud at depths between 120 and $265 \mathrm{~m}$ (Iatrou, 2013). Discards of red mud at sea have ranged between 500,000 and 700,000 tonnes annually (Papatheodorou et al., 1999; Pontikes, 2007; Varnavas and Achilleopoulos, 1995; Varnavas et al., 1986). In 2006, the factory introduced filter presses as a mitigation measure, and in 2011 it was reported to have stopped discarding red mud at sea (Issaris et al., 2012; and see http://www.alhellas.com). Two main deposits of red mud have been located on the seafloor: a coastal deposit covering $36 \mathrm{~km}^{2}$ (with an estimated volume of 41 million $\mathrm{m}^{3}$ ), and an offshore deposit covering $288 \mathrm{~km}^{2}$ (with an estimated volume of 2 million $\mathrm{m}^{3}$ ) (Iatrou, 2013; Iatrou et al., 2010a,b). Fig. 1 shows the estimated expanse of red mud deposits (based on Iatrou, 2013).

\subsection{Survey and Photo-Identification Effort}

We used $5.8 \mathrm{~m}$ long inflatable crafts with rigid hulls, powered by $100 \mathrm{HP}$ four-stroke outboard engines, from May to October between the years 2011 and 2015, totalling 211 survey days, $1344 \mathrm{~h}$ at sea, and 21,435 km of navigation (Table 1; Fig. 2). Navigation was conducted under the following conditions: (1) daylight and long-distance visibility, (2) sea state $\leq 2$ Douglas, (3) at least two experienced observers scanning the sea surface, (4) eye elevation of $1.6-1.8 \mathrm{~m}$, and (5) survey speeds between 26 and 
Table 1 Summary of Research Effort Surveying for Delphinid Species in the Gulf of Corinth (2011-2015)

\begin{tabular}{|c|c|c|c|c|c|c|}
\hline Year & 2011 & 2012 & 2013 & 2014 & 2015 & Total \\
\hline Survey days & 31 & 28 & 49 & 52 & 51 & 211 \\
\hline Survey effort (km) & 4171 & 3362 & 4243 & 4514 & 5145 & 21,435 \\
\hline $\begin{array}{l}\text { Days with striped } \\
\text { dolphin encounters }\end{array}$ & 21 & 20 & 30 & 31 & 30 & 132 \\
\hline $\begin{array}{l}\text { Days with bottlenose } \\
\text { dolphin encounters }\end{array}$ & 7 & 7 & 9 & 13 & 9 & 45 \\
\hline $\begin{array}{l}\text { Tracking: striped } \\
\text { dolphins }(\mathrm{km})\end{array}$ & 316 & 342 & 450 & 382 & 383 & 1873 \\
\hline $\begin{array}{l}\text { Tracking: bottlenose } \\
\text { dolphins }(\mathrm{km})\end{array}$ & 17 & 53 & 84 & 104 & 77 & 335 \\
\hline $\begin{array}{l}\text { Observation time: } \\
\text { striped dolphins }\end{array}$ & $\begin{array}{l}51 \mathrm{~h} \\
49 \mathrm{~min}\end{array}$ & $\begin{array}{l}52 \mathrm{~h} \\
30 \mathrm{~min}\end{array}$ & $\begin{array}{l}76 \mathrm{~h} \\
22 \mathrm{~min}\end{array}$ & $\begin{array}{l}64 \mathrm{~h} \\
45 \mathrm{~min}\end{array}$ & $\begin{array}{l}65 \mathrm{~h} \\
02 \mathrm{~min}\end{array}$ & $\begin{array}{l}310 \mathrm{~h} \\
28 \mathrm{~min}\end{array}$ \\
\hline $\begin{array}{l}\text { Observation time: } \\
\text { bottlenose dolphins }\end{array}$ & $\begin{array}{l}3 \mathrm{~h} \\
08 \mathrm{~min}\end{array}$ & $\begin{array}{l}9 \mathrm{~h} \\
13 \mathrm{~min}\end{array}$ & $\begin{array}{l}16 \mathrm{~h} \\
28 \mathrm{~min}\end{array}$ & $\begin{array}{l}21 \mathrm{~h} \\
59 \mathrm{~min}\end{array}$ & $\begin{array}{l}16 \mathrm{~h} \\
22 \mathrm{~min}\end{array}$ & $\begin{array}{l}67 \mathrm{~h} \\
10 \mathrm{~min}\end{array}$ \\
\hline $\begin{array}{l}\text { Photos: striped } \\
\text { dolphins (total) }\end{array}$ & 9979 & 11,167 & 14,254 & 11,563 & 13,629 & 60,592 \\
\hline $\begin{array}{l}\text { Photos: bottlenose } \\
\text { dolphins (total) }\end{array}$ & 281 & 1246 & 1032 & 1809 & 1134 & 5502 \\
\hline
\end{tabular}

Numbers for striped dolphins (Stenella coeruleoalba) include counts from both single-species and mixedspecies (with short-beaked common dolphins, Delphinus delphis, and/or with the single Risso's dolphin, Grampus griseus, encountered) groups. Common bottlenose dolphins (Tursiops truncatus) were only encountered in single-species groups.

$30 \mathrm{~km} / \mathrm{h}$. Navigation was interrupted as soon as dolphins and other marine fauna were observed. Whenever possible, we attempted to obtain photographs or videos of marine fauna (sea turtles, fishes, cephalopods, etc.) to assist in identifying the species and estimating body size.

We spent a total of $378 \mathrm{~h}$ observing and tracking dolphins (Fig. 3), following them with the boat and recording the boat's position with a GPS at 1 min intervals. Striped dolphins and mixed-species groups were followed for $310 \mathrm{~h} 28 \mathrm{~min}$ (mean $=41 \mathrm{~min}$ per encounter, $\mathrm{SD}=44.2, n=457$ encounters), across $1873 \mathrm{~km}$, and on a total of 132 days; bottlenose dolphin groups were followed for $67 \mathrm{~h} 10 \mathrm{~min}$ (mean $=76 \mathrm{~min}$ per encounter, $\mathrm{SD}=77.3, n=53$ encounters), across $335 \mathrm{~km}$, on 45 days. The size and composition of dolphin groups were estimated using counts performed at 


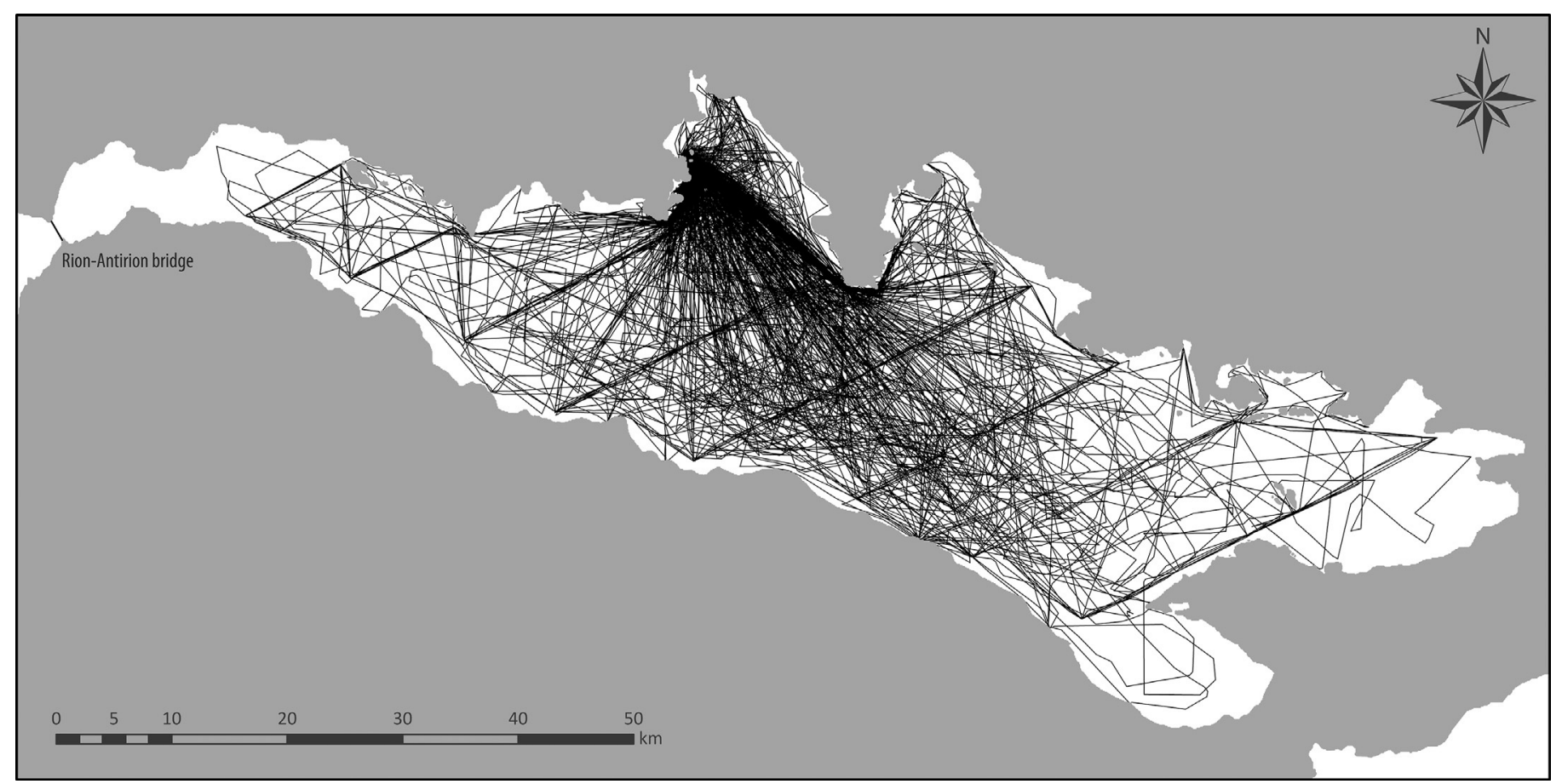

Fig. 2 Survey effort (navigation tracks) in the Gulf of Corinth, during the five-year study period (2011-2015). 


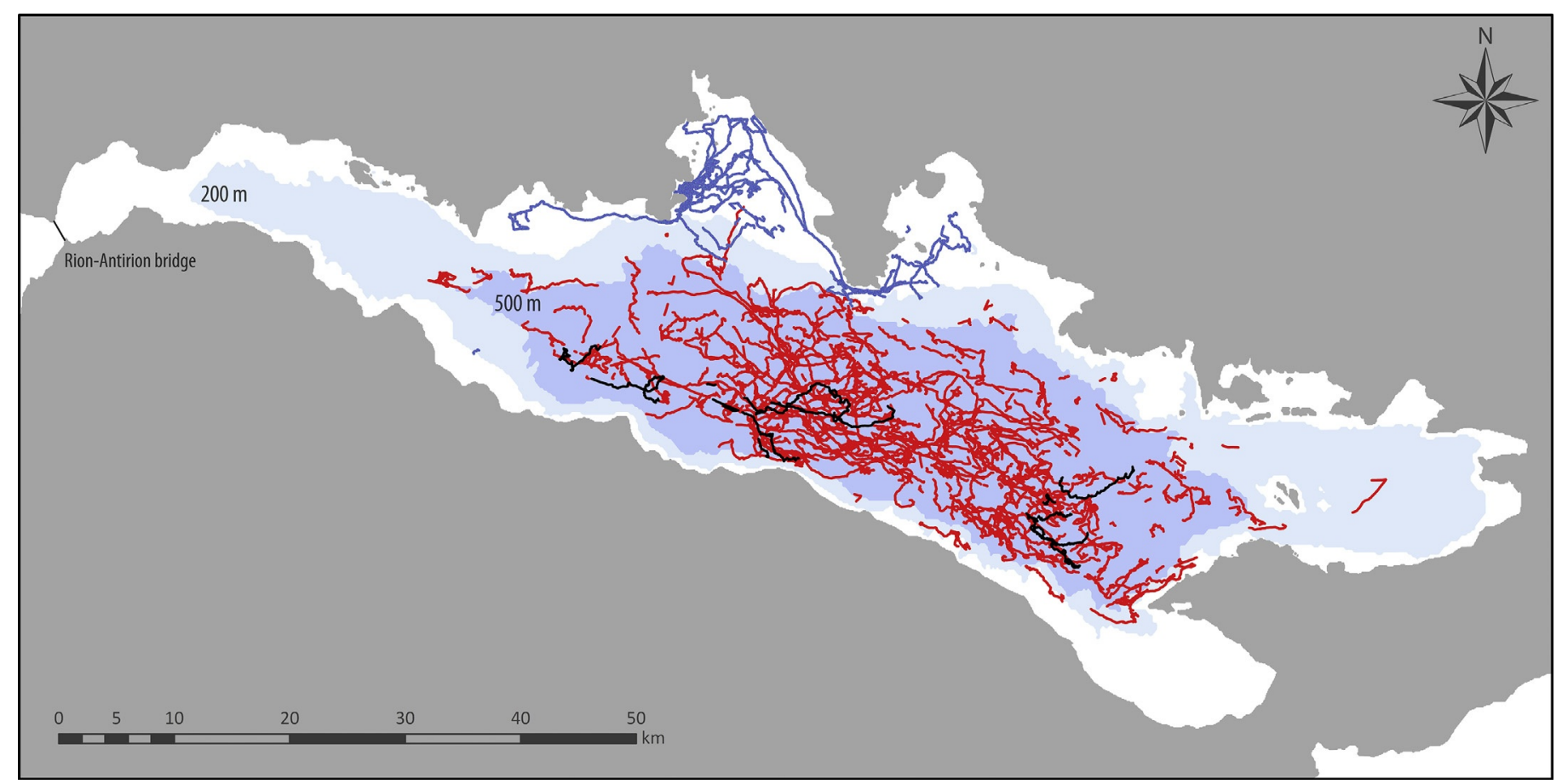

Fig. 3 Dolphin movements plotted based on GPS positions during $378 \mathrm{~h}$ of tracking in the Gulf of Corinth. Red (light grey in the print version): striped dolphins (Stenella coeruleoalba) (occasionally with short-beaked common dolphins, Delphinus delphis, and with individuals of intermediate pigmentation); black: Risso's dolphin (Grampus griseus; always in mixed-species groups with striped dolphins); blue (dark grey in the print version): common bottlenose dolphins (Tursiops truncatus). Shading indicates 200 and $500 \mathrm{~m}$ isobaths. 
15-min intervals. Groups were defined as 'dolphins observed in apparent association, moving in the same direction and often, but not always, engaged in the same activity' (Shane, 1990). Members of the focal group usually remained within approximately $100 \mathrm{~m}$ of each other and were all potentially photo-identifiable. To account for the difficulty of estimating the size of large, dispersed groups, counts above 15 individuals were attributed to categories (16-20, 21-30, 31-50, 51-75, 76-100, 101-150, etc.), using mid values within each category as best estimates. Distant (outlying) animals other than focal group members ('dolphins in sight'; Bearzi et al., 1997) were not included in the count but their occurrence was always recorded.

While tracking dolphins we attempted to photograph each individual in the focal group, irrespective of species, dorsal fin markings, or body size. Photo-identification was performed following Würsig and Jefferson (1990), using 18-megapixel digital cameras equipped with 70-200 mm f2.8 AF zoom lenses. Photographs suitable for individual identification were obtained on 158 days. Of 66,094 digital photos taken, 50,391 were selected based on recommendations by Read et al. (2003). These were cropped around the dorsal fin and visible parts of the body, and further subset using consistent criteria independent of fin markings (high sharpness, entire dorsal fin visible, and perpendicular to camera, no water spray masking fins), resulting in 26,704 high-quality, high-resolution photographs of single individuals. Images were then matched based on conspicuous dorsal fin markings (Bearzi et al., 2011a; Würsig and Würsig, 1977). Animals with absent or inconspicuous markings were considered unidentified. Strict selection, scoring, and matching criteria helped meet the 'mark recognition assumption' in capture-recapture analyses (Bearzi et al., 2011a; Wilson et al., 1999). Much attention was devoted to detecting possible mark changes over time (Gowans and Whitehead, 2001; Wilson et al., 1999).

\subsection{Mixed Groups}

Because striped and common dolphins (as well as individuals of pigmentation that appear to be intermediate between the two species) have similar size and morphology, in mixed groups one cannot discriminate between the two species based on photographs showing only their dorsal fins. Therefore, these individuals were considered together in capture-recapture analyses. The ratio of each species was then estimated based on a subset of 1175 photographs of animals showing sufficiently large body portions during aerial 


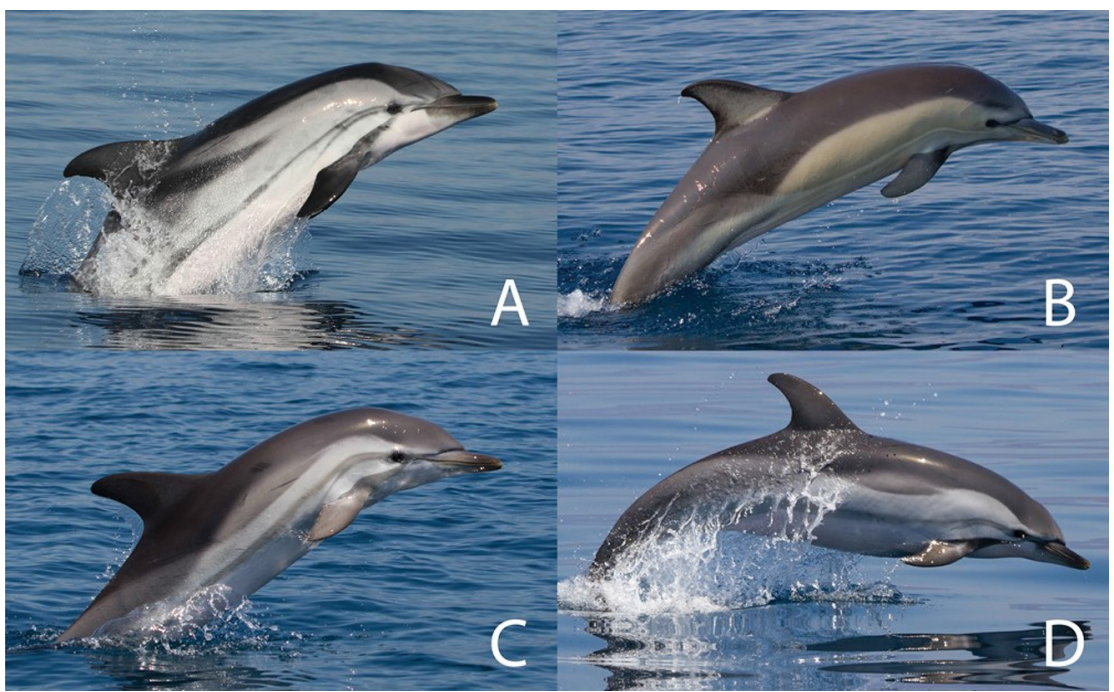

Fig. 4 Examples of photographs showing sufficiently large body portions during aerial behaviour or conspicuous surfacing, used to estimate the proportion of striped dolphins (Stenella coeruleoalba) (A), short-beaked common dolphins(Delphinus delphis) (B), and individuals with intermediate pigmentation (C), in the Gulf of Corinth. If assessors were unable to attribute a category A, B, or C, or they attributed different categories, the photo was scored as 'controversial' (D).

behaviour or conspicuous surfacing, based on the method described by Bearzi et al. (2011a). This subset of photographs, extracted from a dataset of 23,995 photographs of striped dolphin groups, was also used to assess the proportion of common dolphins and animals of intermediate pigmentation (Fig. 4), which were quite distinctive from the known pattern and pigmentation variability of either species (see Rosso et al., 2008).

Criteria for selecting and scoring photographs in this study were considerably more rigorous than those used in the study by Bearzi et al. (2011a), which relied on a comparatively smaller sample size. Retained images had $100 \%$ agreement between two independent assessors with $15+$ years of experience. If assessors were unable to attribute a species category (exemplified by photos A, B, and C in Fig. 4), or they attributed different categories, the image was considered 'controversial' (e.g. photo D in Fig. 4) and was discarded from the analysis. The final abundance estimate was corrected using the proportion of photographs of each species, and a coefficient of variation was calculated and incorporated in the final abundance estimate of each species, following Bearzi et al. (2011a). 


\subsection{Capture-Recapture Analyses}

Striped, common, and intermediate dolphins were indistinguishable using dorsal fin photos alone, and they were treated as a single dataset in capture-recapture analyses. Therefore, we worked on two separate datasets: one for striped, common, and intermediate dolphins collectively, and one for bottlenose dolphins. We created a capture history (in our case, a photographic record) for each individual dolphin; a detection event in a sampling occasion was denoted as 1 and a nondetection as 0 . To obtain a combined abundance estimate of striped, common, intermediate, and bottlenose dolphins, we used capture-recapture models within Pollock's robust design (Kendall et al., 1997; Pollock, 1982). These models relied on maximum likelihood estimation procedures (White and Burnham, 1999) expressing the probability of the observed data (capture history frequencies) as a function of population parameters such as population abundance and detection probability. These parameters were then estimated as the values that maximise the likelihood function (Lebreton et al., 1992). Analyses were carried out using the package RMark (Laake, 2013) in program R (R Core Team, 2014) to construct models from program MARK (White and Burnham, 1999).

Estimates obtained from capture-recapture models relate only to the marked proportion of the population (Read et al., 2003; Wilson et al., 1999). To estimate total population size, we scaled the estimates based on the proportion of identified individuals (Bearzi et al., 2011a; Williams et al., 1993). The variance of the abundance estimates was calculated following Wilson et al. (1999) as:

$$
\operatorname{Var}\left(N_{\text {tot }}\right)=N_{\text {tot }}^{2}\left(\frac{\operatorname{var} N}{N^{2}}+\frac{1-\theta}{n \theta}\right)
$$

where $n=$ number of animals captured, $N=$ estimate of number of marked animals, $\theta=$ proportion of identifiable animals, $N_{\text {tot }}=$ estimate of total population size after correcting for proportion of identifiable individuals, and $\operatorname{var} N=$ variance of marked animals.

\subsection{Distribution Modelling}

To assess factors influencing dolphin distribution, survey data were linked to a variety of geographic, bathymetric, oceanographic, and anthropogenic variables. During surveys and dolphin group follows, GPS positions were recorded every $1 \mathrm{~min}$. Only data collected under sea state S1 (flat), S2 (calm but rippled), and S3 (nonbreaking wavelets less than $20 \mathrm{~cm}$ high) were used 
(Bonizzoni et al., 2014), corresponding to sea states up to approximately 2 Beaufort. Each position was associated with the following variables: sea state, sampling effort index (to account for variable survey effort across the Gulf), latitude, longitude, sea surface temperature (SST), chlorophyll a (Chl-a), upwelling areas, bottom depth, bottom slope, distance to coast, distance to fish farms, distance to coastal red mud deposit, and distance to offshore red mud deposit. Sampling effort index was calculated following Bonizzoni et al. (2014). Sea surface temperature and Chl-a satellite data were obtained from NASA OceanColor (oceancolor.gsfc.nasa.gov) as monthly averaged MODIS-SMI products. Using monthly averaged data, upwelling areas were the regions with negative SST anomalies and positive Chl- $a$ anomalies based on a five-year climatology (2011-2015) for both environmental variables (Valavanis et al., 2004). Bottom depth was obtained from EMODNET (http://www.emodnet-hydrography.eu). All datasets were converted to a gridded surface of points and interpolated to a spatial resolution of $220 \mathrm{~m}$ within ArcGIS (http://www.arcgis.com) to match the mean resolution of field-sampled data. Bottom slope was calculated via spatial analyst tools using GIS software (ESRI ArcMap 10). Active fish farms $(n=17)$ were located through direct observations at sea, nautical charts, and information from Google Earth. Each farm's geometry was mapped with GPS by circumnavigating the farm. Perimeter of red mud deposits was obtained by georeferencing a map in Iatrou (2013). All distances (m) were calculated as minimum distance between the survey point and the corresponding polygon edge of the feature of interest, taking into account coastal profiles, by using the cost distance function within ArcGIS.

The relationships between dolphin presence and these variables were assessed within a modelling framework combining visual survey data and dolphin group follows via generalised additive models (GAM) (Hastie and Tibshirani, 1990; Wood, 2006) and generalised estimation equations (GEE) (Liang and Zeger, 1986), within a framework that has been used previously (Bonizzoni et al., 2014; Pirotta et al., 2011). Briefly, binomial GAM with a logit link was employed. To prevent overfitting by GAM, each explanatory variable was given a maximum number of degrees of freedom (df) to restrict flexibility (Ciannelli et al., 2008). GEE allow for relaxed assumptions of independence among GPS positions within autocorrelated blocks (assigned as in Bonizzoni et al., 2014), but maintain independence among blocks. A simple working independence model was identified as the most appropriate correlation structure for GEE, as advised by Pan (2001). To construct models, GEE-generalised linear models (GEE- 
GLM) were first constructed in $\mathrm{R}$ with the 'geepack' package (Højsgaard et al., 2016) in $\mathrm{R}$ ( $\mathrm{R}$ Core Team, 2014), and then the package 'splines' was used to allow for smoothing splines within the GEE-GLM, resulting in GAM-GEE (Bonizzoni et al., 2014; Pirotta et al., 2011).

A framework of four submodels (geographic, bathymetric, oceanographic, and anthropogenic) was used to describe dolphin presence by incorporating subsets of the 13 variables in GAM and GEE (as in Bonizzoni et al., 2014). This framework of multiple submodels was used because a single global model with all variables suffered from collinearity, as demonstrated by variance inflation factors (VIF) of multiple variables exceeding four. Latitude and longitude were entered within the geographic submodel; bottom depth, bottom slope, and distance to the coast within the bathymetric submodel; SST, Chl- $a$, and distance to nearest upwelling area within the oceanographic submodel; distance to nearest fish farm and distance to red mud deposits within the anthropogenic submodel. This framework allows for submodels to be complementary rather than competing (Planque et al., 2011), and for the identification of a variety of factors correlated to dolphin occurrence. Effort index and sea state were included in all submodels to account for sampling bias. Prior to stepwise selection, multicollinearity was investigated for each submodel via VIF. Explanatory variables with $\mathrm{VIF} \geq 4$ (distance to offshore red mud deposit in the bottlenose dolphin dataset, and distance to coastal red mud deposit in the striped dolphin dataset) were removed from the analyses. The importance of variables was investigated by using a manual backward stepwise selection procedure based on minimising the quasi-likelihood under the independence model criterion (QIC) value (Pan, 2001).

\subsection{Assessment of Fishing Fleets}

Information on the composition of regional fishing fleets is essential for management and it can help estimate important information such as biomass of fish landed and food-web impacts on dolphins and other species (Bearzi et al., 2010; Piroddi et al., 2011b). Because little information existed on fishing effort in the GOC, and use of official fleet registers may be misleading (Gonzalvo et al., 2011), in September 2013 we catalogued all the fishing boats in 47 ports, docks, and roadsteads in the GOC (Fig. 1). Concealed fishing shelters were located by using nautical charts and Google Earth. Fishing boats were photographed and filed in a database that includes boat length, fishing gear, and activity (see Bearzi et al., 2010). 


\section{RESULTS}

\subsection{Striped and Short-Beaked Common Dolphins}

During the five years of the study, we photo-identified a total of 393 striped and common dolphins that were categorised as marked individuals. The proportion of marked animals was 0.25 (95\% CI 0.22-0.27). Our five-year average of the annual estimates of abundance obtained through capturerecapture methods, combining groups of striped dolphins only and mixedspecies groups, was 1401 animals (95\%CI 1241-1582; CV 0.06), with annual point estimates ranging between 1288 and 1534 and insignificant interannual variability $(p>0.05$ for all pairwise $z$-test between years with Bonferroni corrections for multiple testing; Lebreton et al., 1992). Based on photographs of animals showing sufficiently large body portions during aerial behaviour or conspicuous surfacings, the proportion of striped dolphins was estimated as 0.9453 (CV 0.0191), common dolphins 0.0158 (CV 0.2830), and individuals of intermediate pigmentation 0.0389 (CV 0.3668). Considering these proportions and all the associated uncertainties (Bearzi et al., 2011a), we obtained final abundance estimates of 1324 striped dolphins (95\%CI 1158-1515; CV 0.07), 22 common dolphins (95\%CI 16-31; CV 0.17), and 55 intermediates (95\%CI 36-83; CV 0.22). Across the five years of the study, the ratio of common dolphins versus intermediate animals showed a markedly negative trend, dropping from 1.0 in 2011 down to 0.38 in 2015 . However, a linear regression failed to support such hypothesis $\left(R^{2}=0.77, p=0.052\right)$, likely due to the short duration of our study $(n=5)$.

The mean size of striped dolphin and mixed-species groups was 37 animals (SD $=33.1, n=1170$, range 1-225). Occurrence of distant individuals that were not included in the count was recorded during 639 samples $(55 \%)$. When occurrence of common dolphins could be confirmed, groups were significantly larger (mean $=45$ animals, $\mathrm{SD}=31.1, n=232$, range $5-125$; Mann-Whitney $U=67,754, p<0.001)$.

Distribution models (GAM-GEE) for striped dolphins retained latitude and longitude in the geographic submodel, bottom depth in the bathymetric submodel, Chl- $a$ in the oceanographic submodel, and distance to nearest fish farm as well as distance to offshore red mud deposit in the anthropogenic submodel (Fig. 5). Striped dolphin occurrence was positively affected by bottom depth, and negatively by Chl- $a$ : deep oligotrophic waters were clearly preferred. Occurrence was higher in the central and southern sectors 

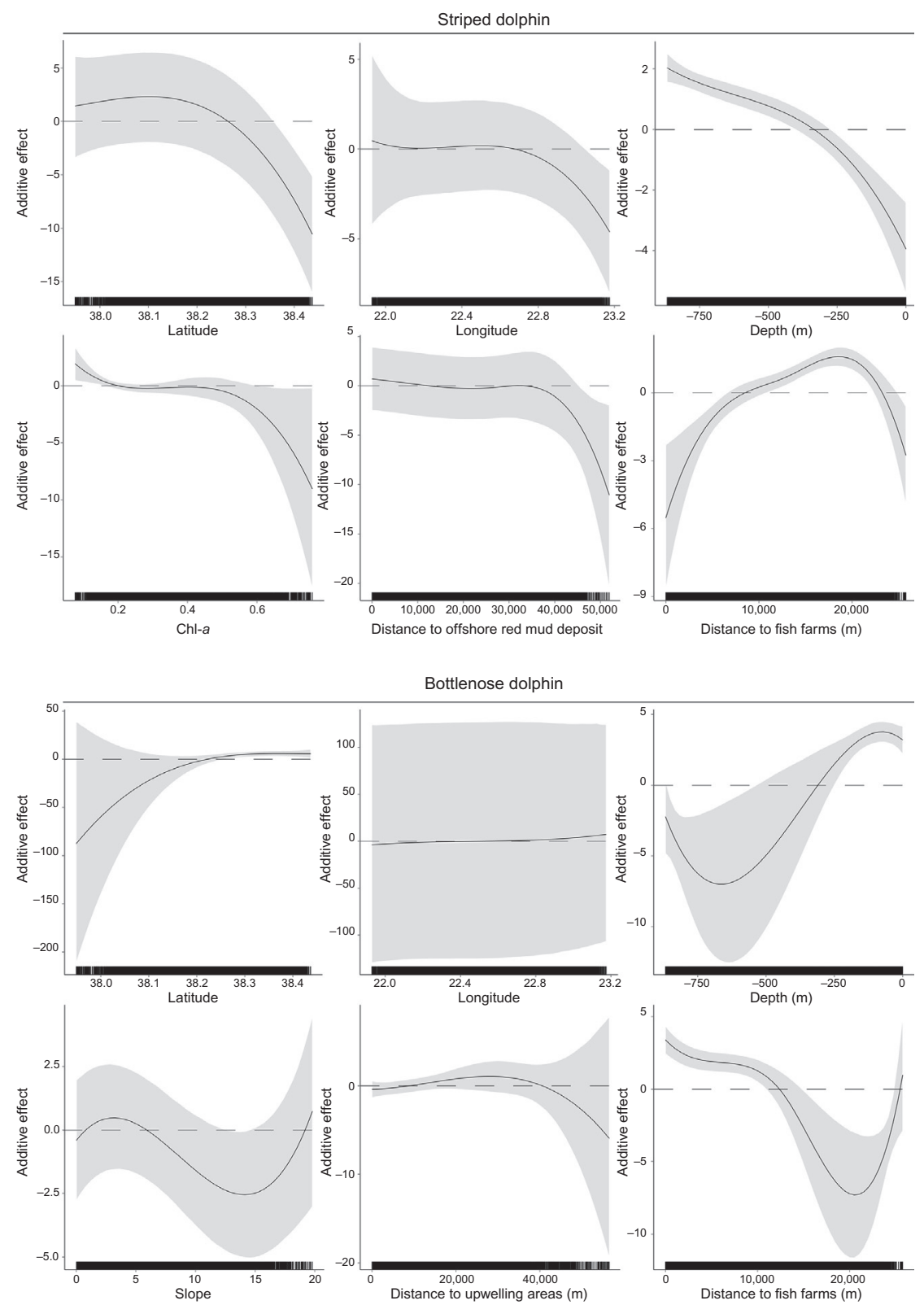

Fig. 5 Response curves of the relationships among explanatory variables and dolphin occurrence in the Gulf of Corinth. Zero on the vertical axes corresponds to no effect of the covariate on the estimated response. Positive values on the vertical axes correspond to a positive relationship between the covariate and presence of dolphins, while negative values correspond to a negative relationship. Shaded areas represent $95 \% \mathrm{Cl}$ as calculated by GEE. 
of the Gulf. Although retained within the geographic submodel, the response curve for longitude shows wide confidence intervals, indicating the modelled increased occurrence in the west is misleading (no observations ever occurred west of $22^{\circ} 08^{\prime} 30^{\prime \prime} \mathrm{E}$ ). Lower occurrence of striped dolphins at distances greater than $40 \mathrm{~km}$ from the offshore red mud deposit likely relates to their strong preference for deep waters (where red mud naturally settles). A subtotal of 119 h 02 min of striped and common dolphin tracking (38.3\% of the total) was conducted in areas over red mud deposits.

\subsection{Risso's Dolphin}

One of the two Risso's dolphins previously photo-identified in the GOC (Frantzis and Herzing, 2002) was never encountered. The only Risso's dolphin encountered was an adult female with characteristic dorsal fin and body markings, including a healed shark bite. This animal was encountered in each year between 2011 and 2015 (a total of 12 days). Consistent with previous findings (Frantzis and Herzing, 2002), the Risso's dolphin was observed within groups of striped and common dolphins, and never alone. Based on movements tracked across $114 \mathrm{~km} \mathrm{(24} \mathrm{h} 27 \mathrm{~min}$ ), habitat encompassed waters $296-859 \mathrm{~m}$ deep, $0.7-10.7 \mathrm{~km}$ off the nearest coast. Mean size of mixed-species groups when the Risso's dolphin was present was 44 animals $(\mathrm{SD}=37.1$, range 4-225), distant dolphins being recorded in $71 \%$ of group size samples. Occurrence of striped and/or common dolphin calves was recorded in $45 \%$ of samples, and the Risso's dolphin was often tightly associated with one or more of those calves. Surfacing intervals recorded across eight continuous timing sessions, totalling $10 \mathrm{~h} 48 \mathrm{~min}$ of timing, yielded dives between 2 and $139 \mathrm{~s}$ (mean $=23 \mathrm{~s}, \mathrm{SD}=17.8$, $n=1628$ ). During daytime observations the Risso's dolphin never performed long dives suggestive of feeding behaviour (Bearzi et al., 2011c). Observed behaviours included travelling, milling, physical contact with either of the other dolphin species, occasional playing with jellyfish and plastic bags, wave riding, and bow-riding small boats as well as a $95 \mathrm{~m}$ cargo ship.

\subsection{Common Bottlenose Dolphins}

Across the five years of the study, we photo-identified a total of 48 individual animals that were considered as marked. The proportion of marked animals was 0.704 (95\%CI $0.650-0.757)$. The 2011 estimate (14 animals, 95\%CI 5-39; CV 0.57) was considered unreliable due to insufficient sample size 
(see Table 1). Our final abundance estimate for the years 2012-2015 was 39 animals (95\%CI 33-47; CV 0.10), with annual point estimates ranging between 31 and 56 and insignificant interannual variability $(p>0.05$ for all pairwise $z$-test between years with Bonferroni corrections for multiple testing; Lebreton et al., 1992).

Number of encounters with marked individuals varied widely; only three were encountered in every year of this study, 23 in three or four of the years, 10 in two of the years, and 12 were only encountered in one of the years. Six of 48 marked individuals observed in the GOC between 2011 and 2015 were previously identified in other parts of Greece (Bearzi et al., 2005, 2010, 2011b). Bottlenose dolphin groups were composed of a mean of eight individuals ( $\mathrm{SD}=4.5, n=259$, range $1-28), 16 \%$ of samples including distant (outlying) dolphins not included in the count.

Distribution models (GAM-GEE) for bottlenose dolphins retained latitude and longitude in the geographic submodel, bottom depth and bottom slope in the bathymetric submodel, distance to upwelling areas in the oceanographic submodel, and distance to nearest fish farm in the anthropogenic submodel (Fig. 5). Bottlenose dolphins occurred predominantly in the northern sector of the Gulf. The response curve for longitude shows wide confidence intervals and no influence is apparent. The response curve for bottom depth indicates higher occurrence in waters shallower than approximately $300 \mathrm{~m}$, whereas the response curve for slope suggests preference for gentler bottom contours. Confidence intervals around steeper slope values are wider and the exact trend of the estimated relationship should be interpreted with caution. Distance to upwelling areas suggests lower occurrence away from productive areas, though past $40 \mathrm{~km}$ the negative relationship has wide confidence intervals. Bottlenose dolphin occurrence was higher in areas within approximately $10 \mathrm{~km}$ of fish farms, and increased in their immediate proximity. A subtotal of $6 \mathrm{~h} 20 \mathrm{~min}$ of bottlenose dolphin tracking (9.4\% of the total) was conducted in areas over red mud deposits.

\subsection{Other Marine Fauna}

Here, we provide a brief account of the marine fauna encountered during boat surveys conducted during the five-year study period.

\subsubsection{Mediterranean Monk Seal (Monachus monachus)}

We encountered a single monk seal on three occasions (June and July 2014, July 2015) in and around the Bay of Itea. Photographs indicated it was the same adult female, approximately $2 \mathrm{~m}$ long. 


\subsubsection{Sea Turtles}

We encountered 64 loggerhead sea turtles (Caretta caretta). Of these, one had longline protruding from its mouth (we cut the line and released the animal), and three were dead (one also hooked on a longline). One adult was observed feeding on the Mediterranean jelly (Cotylorhiza tuberculata). Mean carapace length was $56 \mathrm{~cm}(\mathrm{SD}=11.9$, range $20-80 \mathrm{~cm})$. In August 2012, we encountered a leatherback sea turtle (Dermochelys coriacea) that was approximately $1.5-2 \mathrm{~m}$ long; this is the first reported observation of a living individual in the GOC (Bearzi et al., 2015).

\subsubsection{Fishes}

Scombridae schools were frequently observed feeding at the surface. Of 313 encounters, 35 were 'large tuna' $80-150 \mathrm{~cm}$ long $($ mode $=100 \mathrm{~cm}), 249$ 'small tuna' $30-70 \mathrm{~cm}$ long (mean $=43 \mathrm{~cm}, \mathrm{SD}=7.5$ ), and 29 tuna of undetermined size. Based on photographs, 'small tuna' included juvenile Atlantic bluefin tuna (Thunnus thynnus), little tunny (Euthynnus alletteratus), and Atlantic bonito (Sarda sarda) (in frequent association with flocks of Scopoli's shearwater, Calonectris diomedea), whereas 'large tuna' were mostly bluefin. Myliobatidae (likely giant devil ray, Mobula mobular) were observed once in July 2015: two individuals of $2 \mathrm{~m}$ disc width. Swordfish (Xiphias gladius) totalled 70 individuals (mean $=138 \mathrm{~cm}, \mathrm{SD}=39.2$, range 40-250). Other fish included sunfish (Mola mola; 10 individuals) and unidentified flyingfish (14 individuals $5-30 \mathrm{~cm}$ long). Under floating debris we observed juveniles of common dolphinfish (Coryphaena hippurus), greater amberjack (Seriola dumerili), wreckfish (Polyprion americanus), imperial blackfish (Schedophilus ovalis), grey triggerfish (Balistes capriscus), and pilotfish (Naucrates ductor). No sharks were observed during the five-year study period.

\subsubsection{Invertebrates}

Dead cephalopods or parts thereof were found floating adrift in deep pelagic waters on 24 occasions. Species included 19 specimens of the long-armed squid (Chiroteuthis veranyi), three umbrella squid (Histioteuthis bonnellii) and two unidentified parts. Thirteen findings, of which 12 were C. veranyi, occurred while tracking striped dolphins, suggesting that these squidsknown prey of striped dolphins (Öztürk et al., 2007)—could have been killed by them (all squids were fresh and most carried lesions or amputations). Cotylorhiza tuberculata had a massive bloom during August and September 2012, when the entire surface of the Gulf was dotted by these 
jellyfish. Striped and common dolphins were often observed rubbing Cotylorhiza with their bodies as well as blowing them to pieces with their rostra.

\subsection{Fishing Fleet}

Assessments during windy (no-fishing) days can reasonably estimate the number of vessels of a small-scale fishing fleet, considering that most smallscale fishing in Greece is conducted near home ports to reduce operating costs (Tsitsika and Maravelias, 2008). The GOC small-scale fishing fleet included 361 boats: 301 active and 60 inactive. Mean boat size for the active small-scale fleet was $7.6 \mathrm{~m}(\mathrm{SD}=1.67, n=301$, range $5-12)$. Fishing gear was identified for 262 of the fishing boats. Of these, 77\% $(n=202)$ used set nets (either trammel nets, gillnets, or nylon 'Japanese' nets), 12\% $(n=32)$ used longlines, $6 \%(n=15)$ a combination of set nets and longlines, and $5 \%(n=13)$ were beach seiners that also deployed set nets.

The intermediate scale (industrial) fishing fleet included six purse seiners of 15-18 m, one bottom trawler of $20 \mathrm{~m}$, and one longliner of $15-18 \mathrm{~m}$. Purse seiners were occasionally observed fishing illegally in shallow nearshore areas, including in the Bay of Itea where purse seine fishing is banned. Information obtained during this study indicated that a few nonresident bottom trawlers routinely entered the GOC when the winter fishing season opened; the size and impact of this fleet of nomadic trawlers need to be properly assessed.

\section{DISCUSSION}

\subsection{Geographic Isolation and Genetic Differentiation}

Information on geographic and genetic isolation is relevant for management of local populations and can contribute to assessments of their conservation status (IUCN, 2012a). Cetaceans that have restricted ranges and disjunct distributions can become isolated, and are especially vulnerable to anthropogenic impacts. Further divergence can occur as groups become resident within discrete and geographically separated subareas. Studies on common dolphins show a clear population boundary between the western and the eastern Mediterranean Sea, with additional differentiation in the Ionian Sea (Moura et al., 2013; Natoli et al., 2008). Studies on striped and bottlenose dolphins also show evidence of fine-scale population genetic structure within the Mediterranean Basin (Gaspari et al., 2007, 2015a,b). 
Geographic isolation of striped dolphins and common dolphins in the GOC has been proposed based on absence of records in the western quarter of the Gulf and in the adjacent Gulf of Patras (Bearzi et al., 2011a; Frantzis, 2009; Frantzis et al., 2003). Consistent with the hypothesis of geographic isolation, our study yielded no occurrence west of $22^{\circ} 08^{\prime} \mathrm{E}$. Such geographic isolation may have led to genetic differentiation. Genetic evidence from 25 striped dolphins and three common dolphins sampled in the GOC suggested significant differentiation for both species from individuals in the Ionian Sea and other Mediterranean areas (Gkafas, 2011; Gkafas et al., 2007; Moura, 2010; Moura et al., 2013). The GOC's western quarter is comparatively shallower, with a depth of $65 \mathrm{~m}$ under the RionAntirion Bridge. Shallow waters continue west of the bridge due to the continental shelf of the Gulf of Patras and Prokolpos Patron, and thus any pelagic species would need to cross $80+\mathrm{km}$ of waters less than 50-100 m deep to pass between the Ionian Sea and the GOC (Fig. 1). This physiography might have contributed to the apparent fragmentation of striped dolphins, considering that shallow waters have the potential of inhibiting movements of pelagic species, for instance because key prey may not be found in shallow continental shelf areas (Cañadas et al., 2002). The habitat and range of common dolphins, never observed in single-species groups in the GOC, may be influenced by the habitat preferences and movement patterns of striped dolphins.

\subsection{Striped Dolphins}

Striped dolphins are abundant in the GOC and we found their numbers to be one order of magnitude higher than those inferred from early observations (Frantzis, 2009), and also substantially higher than those estimated by Bearzi et al. (2011a). The increase in numbers of individuals encountered in the current study likely relates to insufficient sampling effort in early studies and does not reflect dramatic shifts in striped dolphin abundance (Santostasi et al., 2016). Indeed, our population estimates did not show significant differences across the five years of this study, but research over longer periods of time is needed to detect trends. Even though the population is 'large', we lack a true baseline of historical striped dolphin abundance. In the past, rapidly spreading epizootics, potentially triggered by pollutants and decreased food availability, have decimated Mediterranean striped dolphins (Aguilar, 2000). We would expect the apparently isolated GOC population to be especially vulnerable if an outbreak were to occur. Vulnerability resulting from isolation within the deep-water portion of the GOC requires 
careful monitoring and precautionary management action for this population.

\subsection{Short-Beaked Common Dolphins and Mixed-Species Groups with Striped Dolphins}

Mixed-species groups are thought to occur due to foraging advantages and predator avoidance, as well as social and reproductive benefits (Herzing and Elliser, 2013; Stensland et al., 2003). Frantzis and Herzing (2002) noted that when numbers of Mediterranean common dolphins decline, the animals tend to associate with striped dolphins due to their tendency of staying in large groups. The authors suggested that as the decline continues, common dolphins start 'depending' on striped dolphins, becoming progressively more scattered across mixed-species groups. The two species, however, have different ecological needs and diets (Aguilar, 2000; Bearzi et al., 2003) and while common dolphins may adapt their behaviour to coexist with striped dolphins, changes in habitat and prey likely come at a cost.

Detecting common dolphin abundance trends in the GOC is hampered by insufficient analytical power resulting inter alia from the low number of animals - a classic problem with small populations (Taylor and Gerrodette, 1993). The steep negative trend $\left(R^{2}=0.77\right)$ in the proportion of common dolphins versus dolphins with intermediate pigmentation, suggesting a continuous decline of the former species, was statistically inconclusive given the short duration of this study. Still, the proportion of common dolphins relative to animals of intermediate pigmentation may represent a valuable proxy to assess relative abundance over time.

Based on the available information, common dolphins in the GOC constitute a geographically distinct conservation unit, and likely have little demographic and genetic exchange. These dolphins face a high risk of extinction due to their small population size (22 animals estimated during the 2011-2015 study period), limited distribution, and suspected hybridisation with a 60-fold larger subpopulation of striped dolphins. We suggest that, given the low number of individuals, this subpopulation is likely nonviable (Traill et al., 2010). Under standard criteria provided by the IUCN Red List to assess extinction risk (IUCN, 2012a,b), the subpopulation would qualify as Critically Endangered (Bearzi et al., 2016).

\subsubsection{Possible Striped Dolphin-Short-Beaked Common Dolphin Hybrid Individuals}

Hybridisation, including that among small delphinids (e.g. Amaral et al., 2014; Brown et al., 2014; Silva et al., 2005), is relatively widespread in 
the order Cetacea, suggesting incomplete postmating barriers to interbreeding (Crossman et al., 2016). Species pairs that share a greater number of traits have a higher propensity to hybridise (Crossman et al., 2016). Because striped and common dolphins are closely related (Amaral et al., 2012, 2014; LeDuc et al., 1999), intermating may be likely to occur in mixedspecies groups, possibly resulting in hybridisation (Bérubé, 2009). Hybridisation and introgression are significant threats for rare species coexisting with more abundant species (Allendorf et al., 2001; Levin, 2002), as is the case for common dolphins in the GOC. Hybridisation may lead to local eradication through genetic swamping, where 'pure' species are progressively replaced by hybrids (as suggested by the markedly negative trend in the ratio of common dolphins versus intermediate animals), or by demographic swamping, where population growth rates are reduced due to the expression of deleterious alleles and production of maladaptive hybrids (Rojas-Bracho and Taylor, 1999; Todesco et al., 2016). Population viability analyses taking into account hybridisation would be a valuable tool to assess survival under different scenarios (Allendorf et al., 2013; Van Dyke, 2008; Wolf et al., 2001). Collection of DNA samples from individuals with intermediate patterns of pigmentation, and subsequent molecular genetic analysis will be necessary to determine whether hybridisation has occurred among the striped and short-beaked common dolphins in the GOC.

\subsubsection{Risso's Dolphin Individual in Mixed-Species Groups of Striped Dolphins and Short-Beaked Common Dolphins}

Only one Risso's dolphin was observed in the GOC: an adult female observed in mixed-species groups throughout this study. Lack of historical information prevents understanding of whether Risso's dolphins (Frantzis and Herzing, 2002) used to be regular in the Gulf and have declined to the single individual observed today. Further, no information exists on Risso's dolphin distribution, movements, and abundance in the Ionian Sea, and no sighting records were reported from the Gulf of Patras and adjacent waters.

\subsection{Common Bottlenose Dolphins}

At least some of the bottlenose dolphins observed in the GOC can cross the strait leading to open Ionian Sea waters. Bearzi et al. (2011b) showed that eight of a total of 31 individuals photo-identified in the Gulf in 2009 were sighted in other areas of western Greece, up to $265 \mathrm{~km}$ apart. Though about half of the bottlenose dolphins photo-identified in the GOC showed moderate degrees of site fidelity (having been encountered in the Gulf 
repeatedly), many were only observed sporadically and are unlikely to permanently inhabit the Gulf, where they may return on opportunistic basis. Dispersion and roaming typically increase as a response to low density and patchy distribution of prey, or as a strategy to reduce the likelihood of inbreeding (Silva et al., 2008).

Bottlenose dolphins in the GOC appear to be strongly attracted to fish farms on the northern coast (see Fig. 1). This finding is consistent with observations in other coastal areas of Greece, where fish farms were described as 'a new trophic resource for bottlenose dolphins' (Piroddi et al. 2011a) and these dolphins were described as 'fish farm specialists' (Bonizzoni et al., 2014, 2015). Fish farms can attract wild fish by providing structure, refuge from predators, and food resources (Dempster et al., 2002), with influences extending beyond the immediate vicinity of the farmed area (Machias et al., 2005; Weir and Grant, 2005). Productive waters around fish farms have become important feeding spots for bottlenose dolphins, which seem to travel from one fish farm cluster to the next in search of prey. Such behaviour, possibly a response to prey depletion (Bearzi et al., 2008b) and low prey availability away from fish farms, may prompt movements to distant areas outside of the Gulf. While bottlenose dolphins observed during this study regularly interacted with fish farms and closely approached fish cages (often within $1 \mathrm{~m}$ ), we recorded no evidence of depredation or conflict with farmers.

\subsection{Other Species}

The Mediterranean monk seal-the world's most endangered seal species (Karamanlidis et al., 2016)—was historically common in the GOC. The northern portion of the Gulf reportedly hosted the 'only important population known for continental Greece', particularly in and around the Bay of Antikyra and between Galaxidi and the island of Vroma (see Fig. 1), where approximately 20 monk seals_-including young animals and a breeding colony-were regularly observed between 1969 and 1976 (Marchessaux and Duguy, 1977a,b, 1978). Later on, monk seal populations declined dramatically (Karamanlidis and Dendrinos, 2015), including in the GOC. For instance, Azzolin et al. (2014) reported two encounters with an individual in July 2012, described as the 'first sightings of the century'. Present numbers throughout the GOC are likely to be low, as we only observed a single animal between 2011 and 2015. Mediterranean monk seals, however, have recently shown unsuspected resilience and numbers have the potential to 
increase, given appropriate management (Notarbartolo di Sciara, 2010; Notarbartolo di Sciara and Kotomatas, 2016).

In addition to marine mammals, the GOC hosts a variety of protected species listed in the EU Habitats Directive and other international conservation conventions (Issaris et al., 2012). Our study documents a relatively high occurrence of loggerhead sea turtles, tuna (including juvenile bluefin), and swordfish, as well as of other charismatic and threatened species. To support high numbers of pelagic dolphins, the GOC must host a considerable biomass of epi- and mesopelagic prey, but formal assessments of these communities are lacking. Oceanic cephalopods with circadian vertical movements are likely important prey (Öztürk et al., 2007). Striped dolphin dives indicative of feeding behaviour were infrequent during daytime, but long diving typically increased before sunset, suggesting night-time feeding. Studies on dolphin (acoustic) behaviour at night, and investigations on distribution, abundance, and vertical movements of epi- and mesopelagic fauna (particularly deep-water cephalopods) could provide important data to increase our understanding of delphinid biology and ecology in the Gulf.

\subsection{Anthropogenic Impacts}

Though a colossal amount of red mud was discarded into the GOC for over half a century, effects on local marine food webs are unknown. Environmental concerns caused by disposal of red mud relate to its high alkalinity and sodicity (Paramguru et al., 2005; Power et al., 2011) and its documented hazards to sea life (Blackman and Wilson, 1973; Dauvin, 2010; Dethlefsen and Rosenthal, 1973; Pagano et al., 2002). Because red mud is a valuable resource that can be reused (e.g. Paramguru et al., 2005; Pontikes and Angelopoulos, 2013), systematic dumping of millions of tonnes at sea, let alone within a semienclosed Gulf such as the GOC, is not only hazardous but also wasteful. High levels of metals were found in seagrass (Posidonia oceanica) from the Bay of Antikyra (Malea et al., 1994), an area where levels of polycyclic aromatic hydrocarbons in sediments, and concentrations of polychlorinated biphenyls (PCBs) and dichlorodiphenyl trichloroethane and its metabolites (DDTs) in Mediterranean mussels (Mytilus galloprovincialis) were among the highest sampled throughout Greece (Botsou and Hatzianestis, 2012; Tsangaris et al., 2010, 2011). In the present study, distribution modelling showed no strong correlation between red mud deposits and dolphin occurrence. Because striped dolphins tend to be epi- and mesopelagic feeders and red mud dumping impacts 
predominantly the seafloor, avoidance would not be expected. However, indirect effects such as contamination up the food web are possible (Jepson et al., 2016). Bottlenose dolphins are primarily benthic feeders, and thus any use of the area is likely to result in direct and indirect exposure to toxic contaminants, with unknown health effects. On one occasion, bottlenose dolphins in the Bay of Antikyra were observed surfacing covered by red mud, indicating bottom feeding on the coastal deposit. Bottlenose dolphins are opportunistic feeders and they can occur in areas heavily impacted by human activities as long as prey is available (Bearzi et al., 2008b; Bonizzoni et al., 2014). Overlap between dolphin habitat and red mud deposits in the GOC raises concern, considering the immunotoxic and other detrimental effects of environmental pollutants (Desforges et al., 2016; Jepson et al., 2016).

The fishing fleet operating in the GOC is predominantly small scale. Though illegal fishing by purse and beach seiners was observed, current fishing bans and other regulations would contribute to mitigating overfishing if properly enforced. A scarcity of information and lack of baseline data prevent understanding of the past and present impacts of fishing in this area, including potential depletion of dolphin prey. During our study, we interviewed 104 fishers operating in the GOC, and 46 (44\%) mentioned beach seiners, purse seiners, bottom trawlers, or overfishing in general as negatively influencing their catch (S. Bonizzoni and G. Bearzi, unpublished data). Overall, seiners and trawlers scored as the main anthropogenic factor perceived as a threat to fish stock viability in the GOC (also see Bearzi et al., 2008a, 2010). Future studies of fishing capacity should consider an appropriate assessment of the year-round industrial fishing effort and landings, also taking into account instances of illegal fishing and occurrence of incidental mortality in fishing gear of dolphins and other protected species (Macías López et al., 2012; Marçalo et al., 2015). Ecosystem modelling would be a valuable tool to investigate trophic interactions and fisheries-related ecological perturbations (Piroddi et al., 2010, 2011b).

Underwater noise and disturbance are known threats to cetaceans and marine life generally (Nowacek et al., 2007; Würsig and Richardson, 2009). The GOC is an area of great interest for geophysical research, and seismic surveys are not infrequent (e.g. Beckers et al., 2015; Taylor et al., 2011). The impact on cetaceans of noise generated by seismic research is of concern, and its effects should be carefully assessed. Further, cargos and ships up to approximately $100 \mathrm{~m}$, as well as motor yachts of all sizes, have been regularly observed crossing dolphin habitat, sometimes at high speeds. Our photographs included striped dolphins with fresh propeller wounds and 
cut-off dorsal fins, suggesting occurrence of collisions. High-speed sport contests overlapping dolphin critical habitat (e.g. the jet-ski race held in the GOC in 2013; http://www.hjsba.gr, http://www.jetraidgreece.com) pose a high risk of collision and disturbance, and they should be banned.

\subsection{Conclusions}

We demonstrate that much of the GOC's biological wealth has been underestimated. The fate of such a rich natural heritage depends on the enforcement of legislation consistent with commitments to protect marine biodiversity - one of Greece's main treasures. We recommend that new pieces of evidence provided by this study be appropriately incorporated into management plans and spatial planning efforts, and we hope that such evidence will bring about timely action, ensuring mitigation of anthropogenic impacts and long-term protection of a vulnerable inland sea and its cetacean fauna.

\section{ACKNOWLEDGEMENTS}

This study was largely funded by OceanCare. Additional support was received from Andrea Sacchi and Texas A\&M University. Special thanks to Sigrid Lüber, who greatly helped us develop this project. Our thanks also go to Silvia Frey, Vera Bürgi, Fabienne McLellan, and everybody at OceanCare. Thank you Bernd Würsig for opportunities and open doors. We are grateful to our collaborators Mariana Ferreira Da Silveira, Dagmar Knäbel, Sarah Piwetz, Eva Greene, Ana Catarina Cardoso Fonseca, Valeria Senigaglia, Annalucia Cantafaro, Philippa Dell, Riccardo Grigoletto, Manon Roucaute, Nicola Stoppelli, and all the volunteers who contributed to data collection and management. Many thanks to Margarita Iatrou, Paolo Guidetti, Dimitris Andressakis, Thomas Siarmpas, Spiros Giannoulatos, Danila Cuccu, and Patrick Louisy for contributing important information. Thank you Chrisoula Papalexi, Kostas Papalexis, Christos Goultidis, and Alexandra Kaliva for valuable support. We are grateful to two anonymous reviewers whose comments helped improve our manuscript. Field work in Greece, coordinated by the Tethys Research Institute until July 2011, was conducted under research permits issued by the Hellenic Ministry of Environment, Energy, and Climate Change. N.L.S. was supported by a research grant by La Sapienza University of Rome; N.B.F. by a Vanier Graduate Scholarship and a Travel Research Grant provided by the Canadian Society of Zoologists.

\section{REFERENCES}

ACCOBAMS, 2007. Report of the 3rd Meeting of the Contracting Parties to ACCOBAMS, the UNEP/CMS Agreement on the Conservation of Cetaceans of the Black Sea, Mediterranean Sea and Contiguous Atlantic Area, Dubrovnik, Croatia, 22-25 October.

Aguilar, A., 2000. Population biology, conservation threats and status of Mediterranean striped dolphins (Stenella coeruleoalba). J. Cetacean Res. Manag. 2, 17-26.

Aguilar, A., Gaspari, S., 2012. Stenella coeruleoalba (Mediterranean subpopulation). The IUCN Red List of Threatened Species 2012. e.T16674437A16674052. 
Allendorf, F.W., Leary, R.F., Spruell, P., Wenburg, J.K., 2001. The problems with hybrids: setting conservation guidelines. Trends Ecol. Evol. 16, 613-622.

Allendorf, F.W., Luikart, G., Aitken, S.N., 2013. Conservation and the Genetics of Populations, second ed. Wiley-Blackwell, Chichester, UK.

Amaral, A.R., Jackson, J.A., Möller, L.M., Beheregaray, L.B., 2012. Species tree of a recent radiation: the subfamily Delphininae (Cetacea, Mammalia). Mol. Phylogenet. Evol. 64, 243-253.

Amaral, A.R., Lovewell, G., Coelho, M.M., Amato, G., Rosenbaum, H.C., 2014. Hybrid speciation in a marine mammal: the clymene dolphin (Stenella clymene). PLoS One 9, e83645.

Archer, F.I., 2009. Striped dolphin Stenella coeruleoalba. In: Perrin, W.F., Würsig, B., Thewissen, J.G.M. (Eds.), Encyclopedia of Marine Mammals, second ed. Academic Press, Amsterdam, pp. 1127-1129.

Azzolin, M., Anichini, M., Galli, A., Papale, E., Giacoma, C., 2010. Evidence of a striped dolphin (Stenella coeruleoalba) nursery zone in the waters adjacent to the terrestrial Natura 2000 area 'Gerania Mount' (Gulf of Corinth). In: Proceedings 24th Conference European Cetacean Society, Stralsund, Germany, 22-24 March.

Azzolin, M., Papale, E., Giacoma, C., 2014. Mediterranean monk seal (Monachus monachus) in the Gulf of Corinth (Greece): first sightings of the century. In: Proceedings 28th Conference European Cetacean Society, Liège, Belgium, 5-9 April.

Bearzi, G., 2003. Short-beaked common dolphin Delphinus delphis (Mediterranean subpopulation). The IUCN Red List of Threatened Species 2003. e.T41762A10557372.

Bearzi, G., 2007. Marine conservation on paper. Conserv. Biol. 21, 1-3.

Bearzi, G., Notarbartolo di Sciara, G., Politi, E., 1997. Social ecology of bottlenose dolphins in the Kvarneric (northern Adriatic Sea). Mar. Mamm. Sci. 13, 650-668.

Bearzi, G., Reeves, R.R., Notarbartolo di Sciara, G., Politi, E., Cañadas, A., Frantzis, A., Mussi, B., 2003. Ecology, status and conservation of short-beaked common dolphins (Delphinus delphis) in the Mediterranean Sea. Mammal Rev. 33, 224-252.

Bearzi, G., Politi, E., Agazzi, S., Bruno, S., Costa, M., Bonizzoni, S., 2005. Occurrence and present status of coastal dolphins (Delphinus delphis and Tursiops truncatus) in the eastern Ionian Sea. Aquat. Conserv. 15, 243-257.

Bearzi, G., Agazzi, S., Gonzalvo, J., Costa, M., Bonizzoni, S., Politi, E., Piroddi, C., Reeves, R.R., 2008a. Overfishing and the disappearance of short-beaked common dolphins from western Greece. Endanger. Species Res. 5, 1-12.

Bearzi, G., Fortuna, C.M., Reeves, R.R., 2008b. Ecology and conservation of common bottlenose dolphins Tursiops truncatus in the Mediterranean Sea. Mammal Rev. 39, 92-123.

Bearzi, G., Agazzi, S., Gonzalvo, J., Bonizzoni, S., Costa, M., Petroselli, A., 2010. Biomass removal by dolphins and fisheries in a Mediterranean Sea coastal area: do dolphins have an ecological impact on fisheries? Aquat. Conserv. 20, 549-559.

Bearzi, G., Bonizzoni, S., Agazzi, S., Gonzalvo, J., Currey, R.J.C., 2011a. Striped dolphins and short-beaked common dolphins in the Gulf of Corinth, Greece: abundance estimates from dorsal fin photographs. Mar. Mamm. Sci. 27, E165-E184.

Bearzi, G., Bonizzoni, S., Gonzalvo, J., 2011b. Mid-distance movements of common bottlenose dolphins in the coastal waters of Greece. J. Ethol. 29, 369-374.

Bearzi, G., Reeves, R.R., Remonato, E., Pierantonio, N., Airoldi, S., 2011c. Risso's dolphin Grampus griseus in the Mediterranean Sea. Mamm. Biol. 76, 385-400.

Bearzi, G., Fortuna, C.M., Reeves, R.R., 2012. Tursiops truncatus (Mediterranean subpopulation). The IUCN Red List of Threatened Species 2012. e.T16369383A16369386.

Bearzi, G., Casale, P., Margaritoulis, D., Bonizzoni, S., Santostasi, N.L., 2015. Observation of a leatherback sea turtle Dermochelys coriacea in the Gulf of Corinth, Greece. Mar. Turt. Newsl. 146, 6-9. 
Bearzi, G., Bonizzoni, S., Santostasi, N.L., Eddy, L., Gimenez, O., 2016. Short-beaked common dolphins in the Gulf of Corinth are Critically Endangered. In: 1st International Workshop 'Conservation and Research Networking on Short-Beaked Common Dolphin (Delphinus delphis) in the Mediterranean Sea', Ischia Island, Italy, 13-15 April, 2016, p. 42

Beckers, A., Hubert-Ferrari, A., Beck, C., Bodeux, S., Tripsanas, E., Sakellariou, D., De Batist, M., 2015. Active faulting at the western tip of the Gulf of Corinth, Greece, from high-resolution seismic data. Mar. Geol. 360, 55-69.

Bérubé, M.B., 2009. Hybridism. In: Perrin, W.F., Würsig, B., Thewissen, J.G.M. (Eds.), Encyclopedia of Marine Mammals, second ed. Academic Press, Amsterdam, pp. 588-592.

Blackman, R.A.A., Wilson, K.W., 1973. Effects of red mud on marine animals. Mar. Pollut. Bull. 4, 169-171.

Bonizzoni, S., Furey, N.B., Pirotta, E., Valavanis, V.D., Würsig, B., Bearzi, G., 2014. Fish farming and its appeal to common bottlenose dolphins: modelling habitat use in a Mediterranean embayment. Aquat. Conserv. 24, 696-711.

Bonizzoni, S., Eddy, L., Würsig, B., Bearzi, G., 2015. Fish farm specialists: bottlenose dolphins in the Southern Evoikos Gulf, Greece. In: Proceedings 29th Conference European Cetacean Society, St. Julians, Malta, 23-25 March.

Botsou, F., Hatzianestis, I., 2012. Polycyclic aromatic hydrocarbons (PAHs) in marine sediments of the Hellenic coastal zone, eastern Mediterranean: levels, sources and toxicological significance. J. Soils Sediments 12, 265-277.

Brown, A.M., Kopps, A.M., Allen, S.J., Bejder, L., Littleford-Colquhoun, B., Parra, G.J., Cagnazzi, D., Thiele, D., Palmer, C., Frère, C.H., 2014. Population differentiation and hybridisation of Australian snubfin (Orcaella heinsohni) and Indo-Pacific humpback (Sousa chinensis) dolphins in north-western Australia. PLoS One 9, e101427.

Cañadas, A., Vázquez, J.A., in press. Common dolphins in the Alborán Sea: facing a reduction in their suitable habitat due to an increase in sea surface temperature. Deep-Sea Res. Pt. II.

Cañadas, A., Sagarminaga, R., García-Tiscar, S., 2002. Cetacean distribution related with depth and slope in the Mediterranean waters off southern Spain. Deep-Sea Res. Pt. I 49, 2053-2073.

Ciannelli, L., Fauchald, P., Chan, K.S., Agostini, V.N., Dingsor, G.E., 2008. Spatial fisheries ecology: recent progress and future prospects. J. Mar. Syst. 71, 223-236.

Crossman, C.A., Taylor, E.B., Barrett-Lennard, L.G., 2016. Hybridization in the Cetacea: widespread occurrence and associated morphological, behavioral, and ecological factors. Ecol. Evol. 6, 1293-1303. http://dx.doi.org/10.1002/ece3.1913.

Dauvin, J.C., 2010. Towards an impact assessment of bauxite red mud waste on the knowledge of the structure and functions of bathyal ecosystems: the example of the Cassidaigne canyon (north-western Mediterranean Sea). Mar. Pollut. Bull. 60, 197-206.

Dempster, T., Sanchez-Jerez, P., Bayle-Sempere, J.T., Giménez-Casalduero, F., Valle, C., 2002. Attraction of wild fish to sea-cage fish farms in the south-western Mediterranean Sea: spatial and short-term temporal variability. Mar. Ecol. Prog. Ser. 242, 237-252.

Desforges, J.P., Sonne, C., Levin, M., Siebert, U., De Guise, S., Dietz, R., 2016. Immunotoxic effects of environmental pollutants in marine mammals. Environ. Int. 86, 126-139.

Dethlefsen, V., Rosenthal, H., 1973. Problems with dumping of red mud in shallow water: a critical review of selected literature. Aquaculture 2, 267-280.

Frantzis, A., 2009. Cetaceans in Greece: present status of knowledge. Initiative for the Conservation of Cetaceans in Greece. Athens, Greece. 94 p. http://thalassaproject.mom.gr/ LH2Uploads/ItemsContent/46/Cetaceans-in-Greece-Present-status-of-knowledge.pdf. 
Frantzis, A., Herzing, D., 2002. Mixed-species associations of striped dolphins (Stenella coeruleoalba), short-beaked common dolphins (Delphinus delphis) and Risso's dolphins (Grampus griseus) in the Gulf of Corinth (Greece, Mediterranean Sea). Aquat. Mamm. 28, 188-197.

Frantzis, A., Alexiadou, P., Paximadis, G., Politi, E., Gannier, A., Corsini-Foka, M., 2003. Current knowledge of the cetacean fauna of the Greek Seas. J. Cetacean Res. Manag. $5,219-232$.

Gaspari, S., Natoli, A., 2012. Grampus griseus (Mediterranean subpopulation). The IUCN Red List of Threatened Species 2012. e.T16378423A16378453.

Gaspari, S., Azzellino, A., Airoldi, S., Hoelzel, A.R., 2007. Social kin associations and genetic structuring of striped dolphin populations (Stenella coeruleoalba) in the Mediterranean Sea. Mol. Ecol. 16, 2922-2933.

Gaspari, S., Holcer, D., Mackelworth, P., Fortuna, C., Frantzis, A., Genov, T., Vighi, M., Natali, C., Rako, N., Banchi, E., Chelazzi, G., Ciofi, C., 2015a. Population genetic structure of common bottlenose dolphins (Tursiops truncatus) in the Adriatic Sea and contiguous regions: implications for international conservation. Aquat. Conserv. $25,212-222$.

Gaspari, S., Scheinin, A., Holcer, D., Fortuna, C., Natali, C., Genov, T., Frantzis, A., Chelazzi, G., Moura, A.E., 2015b. Drivers of population structure of the bottlenose dolphin (Tursiops truncatus) in the Eastern Mediterranean Sea. Evol. Biol. 42, 177-190.

Giakoumi, S., Katsanevakis, S., Vassilopoulou, V., Panayotidis, P., Kavadas, S., Issaris, Y., Kokkali, A., Frantzis, A., Panou, A., Mavrommati, G., 2012. Could European marine conservation policy benefit from systematic conservation planning? Aquat. Conserv. 22, 762-775.

Gkafas, G.A., 2011. Molecular Ecology and Fitness of Striped (Stenella coeruleoalba, Meyen, 1833) and Common (Delphinus delphis, Linnaeus, 1758) Dolphins. Ph.D. thesis, Durham University, Durham, UK. http://etheses.dur.ac.uk/743/.

Gkafas, A., Podiadis, V., Tsigenopoulos, K., Reid, B., Karpouzli, E., Verriopoulos, G., Mamuris, Z., Magoulas, A., Exadactylos, A., 2007. Genetic polymorphism and population structure of the striped dolphin, Stenella coeruleoalba, and the common dolphin, Delphinus delphis, within the ACCOBAMS area. In: Proceedings 10th International Conference on Environmental Science and Technology, Kos Island, Greece, 5-7 September, pp. 426-431.

Gonzalvo, J., Moutopoulos, D.K., Bearzi, G., Stergiou, K.I., 2011. Fisheries mismanagement in a Natura 2000 area in western Greece. Fish. Manag. Ecol. 18, 25-38.

Gowans, S., Whitehead, H., 2001. Photographic identification of northern bottlenose whales (Hyperoodon ampullatus): sources of heterogeneity from natural marks. Mar. Mamm. Sci. 17, 76-93.

Greenpeace, 2007. Gulf of Corinth: A Small Haven of Life. Greenpeace, Greece. (in Greek), $30 \mathrm{p}$.

Hastie, T.J., Tibshirani, R.J., 1990. Generalised Additive Models. Monographs on Statistics and Applied Probabilities, vol. 46. Chapman \& Hall, London.

Herzing, D.L., Elliser, C.R., 2013. Directionality of sexual activities during mixed-species encounters between Atlantic spotted dolphins (Stenella frontalis) and bottlenose dolphins (Tursiops truncatus). Int. J. Comp. Psychol. 26, 124-134.

Højsgaard, S., Halekoh, U., Yan, J., 2016. Generalized estimating equation package version 1.2-0.2. http://CRAN.R-project.org/package=geepack.

Iatrou, M., 2013. The Study of the Dispersion of the Red Mud Slurry in the Central Corinth Gulf Using Geophysical, Sedimentological and Geochemical Approaches. Ph.D. thesis (in Greek), University of Patras, Greece. http://www.didaktorika.gr/eadd/readonline? handle $=10442 / 37557$. 
Iatrou, M., Papatheodorou, G., Geraga, M., Ferentinos, G., 2010a. The study of heavy metal concentrations in the red mud deposits at the Gulf of Corinth, using multivariate techniques. Bull. Geol. Soc. Greece 18, 1018-1028.

Iatrou, M., Papatheodorou, G., Geraga, M., Ferentinos, G., 2010b. Submarine bauxitic tailings disposal: a case study in Corinth Gulf, central Greece. Rapp. Comm. Int. Mer. Médit. 39, 260.

Issaris, Y., Katsanevakis, S., Pantazi, M., Vassilopoulou, V., Panayotidis, P., Kavadas, S., Kokkali, A., Salomidi, M., Frantzis, A., Panou, A., Damalas, D., Klaoudatos, D., Sakellariou, D., Drakopoulou, V., Kyriakidou, C., Maina, I., Fric, J., Smith, C., Giakoumi, S., Karris, G., 2012. Ecological mapping and data quality assessment for the needs of ecosystem-based marine spatial management: case study Greek Ionian Sea and the adjacent gulfs. Mediterr. Mar. Sci. 13, 297-311.

IUCN, 2012a. Guidelines for Application of IUCN Red List Criteria at Regional Levels: Version 4.0. IUCN, Gland.

IUCN, 2012b. Red List Categories and Criteria: Version 3.1, second ed. IUCN, Gland.

Jepson, P.D., Deaville, R., Barber, J.L., Aguilar, A., Borrell, A., Murphy, S., Barry, J., Brownlow, A., Barnett, J., Berrow, S., Cunningham, A.A., ten Doeschate, M., Esteban, R., Ferreira, M., Foote, A.D., Genov, T., Gimenez, J., Loveridge, J., Llavona, A., Martin, V., Maxwell, D.L., Papachlimitzou, A., Penrose, R., Perkins, M.W., Smith, B., de Stephanis, R., Tregenza, N., Verborgh, P., Fernandez, A., Law, R.J., 2016. PCB pollution continues to impact populations of orcas and other dolphins in European waters. Sci. Rep. 6, 18573. http://dx.doi.org/10.1038/srep18573.

Karamanlidis, A., Dendrinos, P., 2015. Monachus monachus. The IUCN Red List of Threatened Species 2015. e.T13653A45227543.

Karamanlidis, A.A., Dendrinos, P., de Larrinoa, P.F., Gücü, A.C., Johnson, W.M., Kiraç, C.O., Pires, R., 2016. The Mediterranean monk seal Monachus monachus: status, biology, threats, and conservation priorities. Mammal Rev. 46, 92-105. http://dx.doi. org/10.1111/mam.12053.

Kendall, W.L., Nichols, J.D., Hines, J.E., 1997. Estimating temporary emigration using capture-recapture data with Pollock's robust design. Ecology 78, 563-578.

Laake, J.L., 2013. RMark: an R interface for analysis of capture-recapture data with MARK: AFSC Processed Rep. 2013-01. Alaska Fish. Sci. Cent., NOAA, Natl. Mar. Fish. Serv., 7600 Sand Point Way, NE, Seattle, WA 98115.

Lebreton, J.D., Burnham, K.P., Clobert, J., Anderson, D.R., 1992. Modeling survival and testing biological hypotheses using marked animals: a unified approach with case studies. Ecol. Monogr. 62, 67-118.

LeDuc, R.G., Perrin, W.F., Dizon, A.E., 1999. Phylogenetic relationships among the delphinid cetaceans based on full cytochrome b sequences. Mar. Mamm. Sci. 15, 619-648.

Levin, D.A., 2002. Hybridization and extinction. Am. Sci. 90, 254-261.

Liang, K.Y., Zeger, S.L., 1986. Longitudinal data analysis using generalized linear models. Biometrika 73, 13-22.

Machias, A., Karakassis, I., Somarakis, S., Giannoulaki, M., Papadopoulou, K.N., Smith, C., 2005. The response of demersal fish communities to the presence of fish farms. Mar. Ecol. Prog. Ser. 288, 241-250.

Macías López, D., García Barcelona, S., Báez, J.C., De la Serna, J.M., Ortiz de Urbina, J.M., 2012. Marine mammal bycatch in Spanish Mediterranean large pelagic longline fisheries, with a focus on Risso's dolphin (Grampus griseus). Aquat. Living Resour. $25,321-331$.

Malea, P., Haritonidis, S., Kevrekidis, T., 1994. Seasonal and local variations of metal concentrations in the seagrass Posidonia oceanica (L.) Delile in the Antikyra Gulf, Greece. Sci. Total Environ. 153, 225-235. 
Marçalo, A., Feijó, D., Katara, I., Araújo, H., Oliveira, I., Santos, J., Ferreira, M., Monteiro, S., Pierce, G.J., Silva, A., Vingada, J., 2015. Quantification of interactions between the Portuguese sardine purse seine fishery and cetaceans. ICES J. Mar. Sci. 72, 2438-2449.

Marchessaux, D., Duguy, R., 1977a. Le phoque moine, Monachus monachus (Hermann, 1779), en Grèce. Mammalia 41, 419-439.

Marchessaux, D., Duguy, R., 1977b. Note sur l'observation du phoque moine, Monachus monachus, en Grèce. In: 25th Congrès-Assemblée plénière, Comité des Vertébrés marins et Céphalopodes, Split, 22-30 October, 1976.

Marchessaux, D., Duguy, R., 1978. Le phoque moine, Monachus monachus, en Grèce. In: Ronald, K., Duguy, R. (Eds.), The Mediterranean Monk Seal. UNEP Technical Series, vol. 1. Pergamon Press, Oxford, pp. 65-84.

Mardikis, I., Podiadis, V., Verriopoulos, G., 1999. High sighting frequency of the pelagic species striped dolphin Stenella coeruleoalba in a closed sea area. Eur. Res. Cetaceans, 13, pp, 244-247.

Moura, A.E., 2010. Investigating the Relative Influence of Genetic Drift and Natural Selection in Shaping Patterns of Population Structure in Delphinids (Delphinus delphis; Tursiops spp.). Ph.D. thesis, Durham University, Durham, UK. http://etheses.dur.ac. $\mathrm{uk} / 755 /$.

Moura, A.E., Natoli, A., Rogan, E., Hoelzel, A.R., 2013. Atypical panmixia in a European dolphin species (Delphinus delphis): implications for the evolution of diversity across oceanic boundaries. J. Evol. Biol. 26, 63-75.

Natoli, A., Cañadas, A., Vaquero, C., Politi, E., Fernandez-Navarro, P., Hoelzel, A.R., 2008. Conservation genetics of the short-beaked common dolphin (Delphinus delphis) in the Mediterranean Sea and in the eastern North Atlantic Ocean. Conserv. Genet. 9, 1479-1487.

Notarbartolo di Sciara, G., 2010. The word's two remaining monk seal species: how many different ways are there of being Critically Endangered? Monachus Guardian 13, 39-41.

Notarbartolo di Sciara, G., Bearzi, G., 2010. National Strategy and Action Plan for the conservation of cetaceans in Greece, 2010-2015. Initiative for the Conservation of Cetaceans in Greece, Athens. 55 p.

Notarbartolo di Sciara, G., Birkun, A., 2010. Conserving Whales, Dolphins and Porpoises in the Mediterranean and Black Seas: An ACCOBAMS Status Report. ACCOBAMS, Monaco.

Notarbartolo di Sciara, G., Kotomatas, S., 2016. Are Mediterranean monk seals (Monachus monachus) being left to save themselves from extinction? In: Notarbartolo di Sciara, G., Podestà, M., Curry, B.E. (Eds.), In: Mediterranean Marine Mammals Ecology and Conservation, Advances in Marine Biology vol. 75. Elsevier, Amsterdam, pp. $\mathrm{xxx}-\mathrm{xxx}$.

Nowacek, D.P., Thorne, L.H., Johnston, D.W., Tyack, P.L., 2007. Responses of cetaceans to anthropogenic noise. Mammal Rev. 37, 81-115.

Öztürk, B., Salman, A., Öztürk, A.A., Tonay, A., 2007. Cephalopod remains in the diet of striped dolphins (Stenella coeruleoalba) and Risso's dolphins (Grampus griseus) in the eastern Mediterranean. Vie Milieu 57, 53-59.

Pagano, G., Meric, S., De Biase, A., Iaccarino, M., Petruzzelli, D., Tünay, O., Warnau, M., 2002. Toxicity of bauxite manufacturing by-products in sea urchin embryos. Ecotoxicol. Environ. Saf. 51, 28-34.

Pan, W., 2001. Akaike's information criterion in generalized estimating equations. Biometrics 57, 120-125.

Papatheodorou, G., Lyberis, E., Ferentinos, G., 1999. Use of factor analysis to study the distribution of metalliferous bauxitic tailings in the seabed of the Gulf of Corinth, Greece. Nat. Resour. Res. 8, 277-286. 
Paramguru, R.K., Rath, P.C., Misra, V.N., 2005. Trends in red mud utilization: a review. Miner. Process. Extr. Metall. Rev. 26, 1-29.

Piroddi, C., Bearzi, G., Christensen, V., 2010. Effects of local fisheries and ocean productivity on the northeastern Ionian Sea ecosystem. Ecol. Model. 221, 1526-1544.

Piroddi, C., Bearzi, G., Christensen, V., 2011a. Marine open cage aquaculture in the eastern Mediterranean Sea: a new trophic resource for bottlenose dolphins. Mar. Ecol. Prog. Ser. 440, 255-266.

Piroddi, C., Bearzi, G., Gonzalvo Villegas, J., Christensen, V., 2011b. From common to rare: the case of the Mediterranean common dolphin. Biol. Conserv. 144, 2490-2498.

Pirotta, E., Matthiopoulos, J., MacKenzie, M., Scott-Hayward, L., Rendell, L., 2011. Modelling sperm whale habitat preference: a novel approach combining transect and follow data. Mar. Ecol. Prog. Ser. 436, 257-272.

Planque, B., Loots, C., Petitgas, P., Lindstrom, U., Vaz, S., 2011. Understanding what controls the spatial distribution of fish populations using a multi-model approach. Fish. Oceanogr. 20, 1-17.

Podiadis, V., Dosi, A., Verriopoulou, A., Trivourea, M., Reichelt, M., Hayes Tieken, R., Brooke, B., Sini, M., Trigonis, V., Mumme, C., Genov, T., Zlatar, V., Büeler, D., Fourniotis Pavlatos, P., Prichard, D., Verriopoulos, G., 2003. The striped dolphins in the Gulf of Korinth, 1996-2002: a comparative study. Eur. Res. Cetaceans, 17, p. 263.

Pollock, K.H., 1982. A capture-recapture design robust to unequal probability of capture. J. Wildl. Manag. 46, 752-757.

Pontikes, Y.T., 2007. Utilisation of Red Mud in the Heavy Clay Industry. Ph.D. thesis (in Greek), University of Patras, Greece.

Pontikes, Y., Angelopoulos, G.N., 2013. Resources, conservation and recycling bauxite residue in cement and cementitious applications: current status and a possible way forward. Resour. Conserv. Recycl. 73, 53-63.

Portman, M., Notarbartolo di Sciara, G., Agardy, T., Katsanevakis, S., Possingham, H., Di Carlo, G., 2013. He who hesitates is lost: why conservation in the Mediterranean Sea is necessary and possible now. Mar. Policy 42, 270-279.

Power, G., Gräfe, M., Klauber, C., 2011. Bauxite residue issues: current management, disposal and storage practices. Hydrometallurgy 108, 33-45.

R Core Team, 2014. R: A Language and Environment for Statistical Computing. R Foundation for Statistical Computing, Vienna, Austria. http://www.R-project.org/.

Read, A.J., Urian, K.W., Wilson, B., Waples, D.M., 2003. Abundance of bottlenose dolphins in the bays, sounds and estuaries of North Carolina. Mar. Mamm. Sci. 19, 59-73.

Rojas-Bracho, L., Taylor, B.L., 1999. Risk factors affecting the vaquita (Phocoena sinus). Mar. Mamm. Sci. 15, 974-989.

Rosso, M., Moulins, A., Würtz, M., 2008. Colour patterns and pigmentation variability on striped dolphin Stenella coeruleoalba in north-western Mediterranean Sea. J. Mar. Biol. Assoc. U.K. 88, 1211-1219.

Santostasi, N.L., Bonizzoni, S., Bearzi, G., Eddy, L., Gimenez, O., 2016. Revised abundance estimates of striped and short-beaked common dolphins in the Gulf of Corinth, Mediterranean Sea. In: Proceedings 30th Annual Conference European Cetacean Society, Funchal, Madeira, 14-16 March.

Shane, S.H., 1990. Comparison of bottlenose dolphin behavior in Texas and Florida, with a critique of methods for studying dolphin behavior. In: Leatherwood, S., Reeves, R.R. (Eds.), The Bottlenose Dolphin. Academic Press, San Diego, pp. 541-558.

Silva, J.M., Silva, F.J.L., Sazima, I., 2005. Two presumed interspecific hybrids in the genus Stenella (Delphinidae) in the Tropical West Atlantic. Aquat. Mamm. 31, 468-472.

Silva, M.A., Prieto, R., Magalhães, S., Seabra, M.I., Santos, R.S., Hammond, P.S., 2008. Ranging patterns of bottlenose dolphins living in oceanic waters: implications for population structure. Mar. Biol. 156, 179-192. 
Stelzenmüller, V., Breen, P., Stamford, T., Thomsen, F., Badalamenti, F., Borja, Á., BuhlMortensen, L., Carlstöm, J., D’Anna, G., Dankers, N., Degraer, S., Dujin, M., Fiorentino, F., Galparsoro, I., Giakoumi, S., Gristina, M., Johnson, K., Jones, P.J.S., Katsanevakis, S., Knittweis, L., Kyriazi, Z., Pipitone, C., Piwowarczyk, J., Rabaut, M., Sørensen, T.K., van Dalfsen, J., Vassilopoulou, V., Vega Fernandez, T., Vincx, M., Vöge, S., Weber, A., Wijkmark, N., Jak, R., Qiu, W., ter Hofstede, R., 2013. Monitoring and evaluation of spatially managed areas: a generic framework for implementation of ecosystem based marine management and its application. Mar. Policy 37, 149-164.

Stensland, E., Angerbjörn, A., Berggren, P., 2003. Mixed species groups in mammals. Mammal Rev. 33, 205-223.

Taylor, B.L., Gerrodette, T., 1993. The uses of statistical power in conservation biology: the vaquita and the northern spotted owl. Conserv. Biol. 7, 489-500.

Taylor, B., Weiss, J.R., Goodliffe, A.M., Sachpazi, M., Laigle, M., Hirn, A., 2011. The structures, stratigraphy and evolution of the Gulf of Corinth rift, Greece. Geophys. J. Int. 185, 1189-1219.

Todesco, M., Pascual, M.A., Owens, G.L., Ostevik, K.L., Moyers, B.T., Hübner, S., Heredia, S.M., Hahn, M.A., Caseys, C., Bock, D.G., Rieseberg, L.H., 2016. Hybridization and extinction. Evol. Appl. 9, 892-908. http://dx.doi.org/10.1111/eva.12367.

Traill, L.W., Brook, B.W., Frankham, R.R., Bradshaw, C.J.A., 2010. Pragmatic population viability targets in a rapidly changing world. Biol. Conserv. 143, 28-34.

Tsakiridis, P.E., Agatzini-Leonardou, S., Oustadakis, P., 2004. Red mud addition in the raw meal for the production of Portland cement clinker. J. Hazard. Mater. B116, 103-110.

Tsangaris, C., Kormas, K., Strogyloudi, E., Hatzianestis, I., Neofitou, C., Andral, B., Galgani, F., 2010. Multiple biomarkers of pollution effects in caged mussels on the Greek coastline. Comp. Biochem. Physiol. C Toxicol. Pharmacol. 151, 369-378.

Tsangaris, C., Hatzianestis, I., Catsiki, V.A., Kormas, K.A., Strogyloudi, E., Neofitou, C., Andral, B., Galgani, F., 2011. Active biomonitoring in Greek coastal waters: application of the integrated biomarker response index in relation to contaminant levels in caged mussels. Sci. Total Environ. 412-413, 359-365.

Tsitsika, E.V., Maravelias, C.D., 2008. Fishing strategy choices of purse seines in the Mediterranean: implications for management. Fish. Sci. 74, 19-27.

Valavanis, V.D., Kapantagakis, A., Katara, I., Palialexis, A., 2004. Critical regions: a GISbased model of marine productivity hotspots. Aquat. Sci. 66, 139-148.

Van Dyke, F., 2008. Conservation Biology: Foundations, Concepts, Applications, second ed. Springer, Berlin.

Varnavas, S.P., Achilleopoulos, P.P., 1995. Factors controlling the vertical and spatial transport of metal-rich particulate matter in seawater at the outfall of bauxitic red mud toxic waste. Sci. Total Environ. 175, 199-205.

Varnavas, S.P., Ferentinos, G., Collins, M., 1986. Dispersion of bauxite red mud in the Gulf of Corinth. Mar. Geol. 70, 211-222.

Vassilopoulou, V., Katsanevakis, S., Panayotidis, P., Anagnostou, C., Damalas, D., Dogrammatzi, A., Drakopoulou, V., Giakoumi, S., Haralabous, J., Issaris, Y., Kavadas, S., Klaoudatos, D., Kokkali, A., Kyriakidou, C., Maina, I., Mavromati, G., Palialexis, A., Sakellariou, D., Salomidi, M., 2012. Application of the MESMA Framework, Case Study: Inner Ionian Archipelago and Adjacent Gulfs: MESMA Report. 240 p.

Weir, L.K., Grant, J.W.A., 2005. Effects of aquaculture on wild fish populations: a synthesis of data. Environ. Rev. 13, 145-168.

White, G.C., Burnham, K.P., 1999. Program MARK: survival estimation from populations of marked animals. Bird Study 46, 120-139. 
Williams, J.A., Dawson, S.M., Slooten, E., 1993. The abundance and distribution of bottlenosed dolphins (Tursiops truncatus) in Doubtful Sound, New Zealand. Can. J. Zool. 71, 2080-2088.

Wilson, B., Hammond, P.H., Thompson, P.M., 1999. Estimating size and assessing trends in a coastal bottlenose dolphin population. Ecol. Appl. 9, 288-300.

Wolf, D.E., Takebayashi, N., Rieseberg, L.H., 2001. Predicting the risk of extinction through hybridization. Conserv. Biol. 15, 1039-1053.

Wood, S.N., 2006. Generalized Additive Models: An Introduction with R. Chapman and Hall/CRC, Boca Raton.

Würsig, B., Jefferson, T.A., 1990. Methods of photo-identification for small cetaceans. Rep. Int. Whal. Comm. Spec. Issue 12, 43-52.

Würsig, B., Richardson, W.J., 2009. Effects of noise. In: Perrin, W.F., Würsig, B., Thewissen, J.G.M. (Eds.), Encyclopedia of Marine Mammals, second ed. Academic Press, Amsterdam, pp. 765-773.

Würsig, B., Würsig, M., 1977. The photographic determination of group size, composition, and stability of coastal porpoises (Tursiops truncatus). Science 198, 755-756.

Zafiropoulos, D., Verriopoulos, G., Merlini, L., 1999. Geographical distribution of small cetaceans in several Greek coastal areas. Eur. Res. Cetaceans, 13, pp, 282-284. 